\title{
GOOD GOVERNANCE DALAM MEMBANGUN MASA DEPAN INDONESIA
}

Oleh: Abd. Holik*

\begin{abstract}
This writing attempts to lift phenomena of the presidential election that occurred in Indonesia, where the real transfer of power (succession) is a necessity that occurs every five years. Seeing this phenomenon brings to the understanding that the selection should be used as a vehicle to remain utilize common sense, so appears virtue is constantly being developed and perpetuated togetherat the same time cohabitation conflictual between two things of contradiction that can be dammed as much as possible. In case this is related democracy with oligarchy, democracy coupled with structured crime neatly and such. The issue is raised in an effort to keep perpetuating the concept of good governance in order to achieve good governance. The bid to earthing concept of good governance to build a future in Indonesia showed significance to be retained and developed together here. For that will be revealed in this writing the application from the concept of good governance with the point of view in Islamic law.
\end{abstract}

Keywords: Good Governance, Indonesia, Reconstruction, and Islamic Law

* Fakultas Syari'ah Institut Agama Islam Bani Fattah Jombang, email: pustakaalfatah@yahoo.co.id 


\section{Pendahuluan}

Saat ini Pertanyaan seputar pemimpin telah menjadi diskursus yang paling penting dan menarik. Seiring dengan akan dilaksanaknnya pemilu yang menyedot perhatian dari berbagai kalangan, lalu kiranya siapakah yang layak menjadi orang No. 1 di Indonesia? Pertanyaan ini rupanya telah menggelayut di pikiran kita dewasa ini.

Berbagai Capres pun bermunculan dipermukaan, entah itu dari kalangan militer, kemudian ada juga dari kalangan pengusaha dan lain-lain. Harus diakui dalam hal kemampuan memimpin bangsa ini kiranya tak dapat dipungkiri lagi kualitas mereka, akan tetapi kita dituntut punya kejelian untuk menentukan pilihan kita. Nampaknya panggung pergumulan politik kian hari akan semakin memanas, karena dapat dipastikan mereka akan semakin menunjukkan gairahnya untuk mencapai tujuan mereka.

Pada kenyataannya, Indonesia untuk masa sekarang dan ke depannya sangat memerlukan good governance. Penerapan good governance tersebut harus menjadi tanggungjawab kita semua. Dalam kondisi seperti sekarang, pemerintah, yang selama ini mendapat tempat yang dominan dalam penyelenggaraan otoritas politik, ekonomi dan administrasi, sulit diharapkan secara sadar dan apa adanya, akan berubah dan menjelma menjadi bagian yang efektif dari good governance Indonesia. Oleh Karena itu, penerapan good governance dalam membangun masa depan Indonesia harus dilakukan melalui tekanan eksternal dari luar birokrasi atau pemerintah, yakni melalui pemberdayaan masyarakat sipil untuk memassifkan keikut sertaan berbagai warga negara dalam mengawal jalannya pemerintahan.

Dalam konteks ini, akankah ke depannya Indonesia dipimpin oleh orang yang bijak atau mengedepankan kearifan yang bermuatan lokal, meminjam istilah MA. Sahal Mahfudh, sehingga Indonesia akan semakin meroket dan bersinar atau sebaliknya. Sejalan dengan itu kita butuh penyegaran untuk Indonesia lebih baik, karena sejatinya kita masih diliputi krisis pemimpin yang dipercaya oleh rakyat. Dalam hal ini Moh. Hatta pernah berpesan dengan kalimat seperti ini: "Krisis ini dapat diatasi dengan memberikan kepada negara pimpinan yang dipercaya. Oleh karena itu krisis ini merupakan krisis demokrasi, perlulah hidup politik diperbaiki, partai-partai mengindahkan dasar-dasar moral dalam segala tindakannya." (Moh Hatta, 11 Juni 1957). 
Jika dilihat dari aspek demokrasi nampaklah negara ini telah mempraktekannya dalam kehidupan berbangsa dan bernegara, akan tetapi masih ada cela-cela yang harus diperbaiki. Dalam konteks ini ternyata masih saja bermunculan gerombolan orang-orang yang ngakunya abdi negara yang berusaha mengeruk keuntungan untuk dirinya dan kelompoknya. Padahal kalau politik kebijaksanaan atau kultural dijalankan dengan baik maka tidak dapat dipungkiri itu merupakan investasi (akhirat) yang buahnya akan mereka tuai kelak di alam sana.

Munculnya disintegrasi dalam tubuh parpol sehingga berakibat destruktif bagi parpol itu sendiri merupakan akibat dari tidak ada upaya mengindahkan dasar-dasar moral dalam segala tindakannya sebagaimana telah disinggung Bung Hatta di atas, sehingga menimbulkan krisis kepercayaan dari masyarakat, kemana suara kami akan kami tuangkan? dan kepada siapa kita akan menjatuhkan pilihan? Jadi dalam konteks ini menuju Indonesia yang lebih baik dan maju adalah dambaan kita semua.

Dalam tulisan ini, kami akan mengemukakan sebuah gagasan good governance yang harus dilakukan oleh Presiden terpilih Indonesia. Sehingga wajah Indonesia ke depannya akan semakin bermartabat.

\section{Pembahasan}

1. Selayang Pandang Tentang Negara

Sebelum kita melangkah lebih jauh untuk membahas good governance yang harus dilakukan oleh Presiden terpilih Indonesia, terlebih dahulu kita akan membahas tentang negara. Istilah negara diterjemahkan dari kata-kata asing staat (bahasa belanda dan jerman); State ${ }^{2}$ (bahasa Inggris); etat (bahasa Prancis). Istilah staat mempunyai sejarah sendiri. Istilah itu mula-mula dipergunakan dalam abad ke-15 di eropa Barat. Anggapan umum yang diterima bahwa kata staat (state, etat) itu dialihkan dari kata bahasa latin status atau statum ${ }^{3}$

Secara etimologi kata status itu itu dalam bahasa Latin klasik adalah suatu istilah abstrak yang menunjukkan keadaan yang

2 Dalam kamus "state" memiliki banyak arti di antaranya: negara, keadaan, kebesaran dan lain-lain. Lihat John M. Echols dan Hassan Shadily, Kamus Inggris Indonesia, (Jakarta: Gramedia, 2008), 553.

${ }^{3}$ Ni'matul Huda, Ilmu Negara, (Jakarta: Rajagrafindo Persada, 2013), 1. 
tegak dan tetap atau sesuatu yang memiliki sifat-sifat yang tegak dan tetap itu. ${ }^{4}$

Secara sederhana negara ${ }^{5}$ adalah suatu organisasi dalam suatu wilayah yang memiliki kekuasaan tertinggi yang sah dan ditaati oleh rakyatnya. ${ }^{6}$

Menurut Grotius, sebelum ada negara, kehidupan rakyat pada suku-suku primitif misalnya, sangat kacau. ${ }^{7} \mathrm{Hal}$ ini disebabkan karena setiap orang bebas untuk melakukan apa saja sesuai dengan kehendaknya. Masyarakat menjadi tidak tertib. Karena alasan inilah maka negara didirikan, dengan kekuasaan yang mutlak. ${ }^{8}$

Dalam konteks negara dengan kekuasaan mutlak, tidak dapat dielakkan lagi, harus ada kepala negara sebagai nahkoda dalam mengarungi kehidupan berbangsa dan bernegara. Lebih jauh lagi kepala negara hendaknya seorang yang jujur dan tegas sehingga terwujudlah kemaslahatan bersama dan kesejahteraan bersama.

Namun pertanyaannya apakah Pemilu kali ini akan berjalan sesuai dengan harapan kita bersama ? Jika mencoba melihat kasus Pemilukada pada penghujung 2013 (2/10/2013), KPK menangkap ketua MK Akil Mochtar karena tertangkap basah menerima suap pemilukada Kabupaten Gunung Mas Kalimantan Tengah yang dilakukan calon Bupati Hambit Bintih. Seorang tersangka korupsi yang jelas diketahui melakukan suap kemudian dimenangkan dan

\section{${ }^{4}$ Ibid.}

5 Menurut pandangan Socrates: semua manusia menginginkan kehidupan aman, tentram dan lepas dari gangguan yang memusnakan harkat manusia. Kala itu orangorang mendambakan ketentraman menuju bukit dan membangun benteng, serta mereka berkumpul disana menjadi kelompok. Kelompok inilah yang oleh Socrates dinamakan polis (satu kota saja). Organisasi yang mengatur hubungan antara orangorang yang ada di dalam polis itu tidak hanya mempersoalkan organisasinya saja, tapi juga tentang kepribadian orang-orang disekitarnya. Socrates menganggap polis identik dengan masyarakat dan masyarakat identik dengan negara. Lihat Abu Daud Busroh, Imu Negara, (Jakarta: Bumi Aksara, 2011), 21.

${ }^{6}$ Miriam Budiardjo, Dasar-Dasar Ilmu Politik, (Jakarta: Gramedia, 2010), 17.

7 Senada dengan Grotius, Thomas Hobbes yang merupakan filsuf dari Inggris mengklaim, bahwa masyarakat chaos modelnya yang ditandai peperangan terusmenerus antar manusia, tidak sepenuhnya khayalan. Hal ini didasarkan pada sebagaimana ditegaskan Hobbes- masyarakat internasional pada masanya. Waktu itu tidak ada otoritas sentral hegemonik yang mampu memasukkan sebuah tatanan kepada bangsa-bangsa. Dengan, berarti berlaku pada semua waktu, raja, perorangan dan otoritas yang berdaulat yang berada dalam sikap perang. Lihat Abdel Wahab El-Affendi, Masyarakat Tak Benegara: Kritik Teori Politik Islam, (Yoyakarta: LKiS, 2012), 81.

${ }^{8}$ Ni'matul Huda, Ilmu Negara........, 39. 
dilantik menjadi pemimpin. Bahkan pada tanggal 20 Desember 2013 KPK menetapkan dan menahan Gubernur Banten Ratu Atut Chosiyah sebagai tersangka dalam kasus suap pemilukada Kabupaten Lebak Banten tahun 2013. ${ }^{9}$

Melihat pada kasus di atas menunjukan bahwa tradisi politik kekuasaan di Negara kita seakan tidak berperikemanusiaan yang pada akhirnya menyebabkan praktek korupsi. Momentum Pemilu bukan hanya sebagai peralihan kekuasaan secara konstitusional tetapi telah dimanfaatkan segelintir elit untuk memperebutkan kekuasaan secara kurang beretika. ${ }^{10}$

Bila kita mencermati makna politik ${ }^{11}$ maka yang terlintas dibenak kita pastinya kepentingan dan kepentingan. Sejalan dengan makna politik tersebut, di mana yang ditonjolkan adalah kepentingan, dalam senyatanya atau kenyataanya politik itu sendiri terdapat beragam warna, di antaranya ialah:

Pertama, politik kebangsaan atau kenegaraan, di mana dalam hal ini yang dikedepankan ialah loyalitas kepada NKRI dan kredo pancasila $^{12}$ sebagai idelogi kenegaraan. Mengedepankan loyalitas

9 "Harapan Pemilu Kita", dalam http://politik.kompasiana.com/2014/03/22/ harapan-pemilu-kita-641518.html

${ }^{10}$ Ibid.

${ }^{11}$ Politik, kalau menurut arti katanya atau secara etimologis berasal dari perkataan bahasa Yunani-purba yaitu polis. Polis adalah kota yang dianggap negara yang terdapat dalam kebudayaan Yunani-Purba, dimana pada waktu itu kota dianggap identik dengan negara, sehingga dengan demikian polis, stadstaat atau the greek citystate ialah tempat-tempat tinggal bersama dari orang-orang biasa selaku para warganya (citizent) dengan pemerintah yang biasanya terletak di atas sebuah bukit dan dikelilingi benteng tembok untuk menjaga keamanan mereka terhadap serangan musuh yang datang dari luar. Kemudian dari istilah polis ini diturunkan dan dihasilkan kata-kata seperti: politeia (segala hal ihwal yang menyangkut polis atau negara), polites (warga kota atau warga negara), politikos (ahli negara), politieke techne (kemahiran politik), politieke episteme (ilmu politik) dan kemudian istilah polis itu diambil oleh orang Romawi yang menghasilkan perkataan "ars politica" (pengetahuan tentang negara atau kemahiran tentang masalah-masalah kenegaraan). Lihat Abu Daud Busroh, Imu Negara, (Jakarta: Bumi Aksara, 2011), 9 .

12 Dengan mengamati lima sila dari pancasila atau pokok-pokok pikiran dalam UUD 1945, hakekat atau substansi pancasila dengan kelima silanya yang terdapat pada ketuhanan, kemanusiaan, persatuan, kerakyatan dan keadilan merupakan prinsip dasar yang menjadi cita-cita dan harapan yang dituju oleh bangsa Indonesia untuk diwujudkan menjadi kenyataan dalam kehidupan pribadi, bermasyarakat, berbangsa dan bernegara. Prinsip-prinsip tersebut telah mengandung tiga masalah pokok dalam kehidupan manusia Indonesia, yaitu bagaimana seharusnya manusia 
kepada NKRI dan kredo pancasila ini menurut penulis adalah hal yang penting, oleh karenanya, bila hal tersebut tidak terwujud niscaya bangsa ini bisa dipastikan akan terurai atau terpecah belah dan perpecahan merupakan hal yang harus dihindari, demi terwujudnya integritas negara kita dan perdamaian antar manusia.

Kedua, politik kerakyatan yang di dalamnya terdapat subtansi untuk selalu melindungi, membentengi ketidak adilan atau diskriminatif dan menerima aspirasi rakyat tanpa membedakan suku, agama dan ras, Dalam hal ini tentunya politik ini harus diwujudkan, oleh karenanya, tatkala politik ini tidak terwujud maka sudah dapat dipastikan nuansa egaliter yang mengedepankan kesamaan antar sesama manusia menjadi sirna.

Ketiga, politik etika, yakni selalu mengedepankan moralitas atau keadaban dalam berpolitik. ${ }^{13}$ Kalau kita menyoroti panggung politik saat ini, tampaknya masih banyak politisi yang sering kali melakukan apologetik, sehingga berimplikasi kepada hilangnya moralitas bangsa dan tentunya ini tidak berbanding lurus dengan

itu berhubungan dengan Tuhan, dirinya sendiri dan lingkungannya. Nilai-nilai pancasila itu timbul dari bangsa Indonesia, sebagai hasil pemikiran filsafat bangsa Indonesia. Nilai-nilai pancasila itu diyakini sebagai filsafat (pandangan hidup) bangsa Indonesia yang baik, benar, adil dan bijaksana dalam memedomani kehidupan bermasyarakat, berbangsa dan bernegara. Lihat Sjechul Hadi Pernomo, "Relevansi Filsafat Hukum Nasional Dan Filsafat Hukum Islam: Suatu Tinjauan Komparatif", Akademika, Vol.14, No.2, (Maret, 2004), 123-124.

13 Francis Fukuyama (1999) menyebutkan bahwa setiap perubahan akan merangsang terjadinya guncangan (disruption). Guncangan karena adanya distingsi (drajat perbedaan reaksi seseorang terhadap berbagai stimulus atau peristiwa yang berbeda) antara nilai baru dengan nilai lama dalam sebuah masyarakat. Lantas karena ketidaksiapan mereka akan guncangan politik, akhirnya mereka melakukan pengebirian dan pengesampingan etika dalam jagad perpolitkan. Pada kenyataannya, etika politik merupakan kristalisasi dari nalar (logika) politik warga bangsa itu sendiri. Ia merupakan muara sintesis dari logika-logika yang berkembang pada ranah publik demi terbangunnya kohesi sosial. Pelanggaran terhadap etika politik dengan sendirinya menandakan matinya nalar kebangsaan dan dapat mengancam integrasi sosial. Aristoteles dalam karya besarnya (magnum opus), nicomachean etichs (kebajikan dan karakter moral yang memainkan peranan penting dalam mendefinisikan etika) menyebutkan bahwa kebaikan bersama merupakan muara etika politik sebuah negara. Dan etika yang baik hanya mungkin tercipta dalam negara yang menyediakan tata aturan yang mengarahkan setiap perilaku warganya demi kebaikan bersama. Dari sini kita bisa mengukur apakah perilaku politik yang berkembang di negeri ini mengarah pada kepentingan bersama (rakyat) atau justru mengkristal menjadi kepentingan kelompok atau pribadi. Lihat A. Bakir Ihsan, Etika dan Logika Berpolitik, (Bandung: Rosdakarya, 1999), 20-21. 
jargon pesan adab dalam agama ${ }^{14}$, yakni rahmatan li al-'ālamīn dalam Islam ${ }^{15}$, cinta kasih dalam Kristen, anti kekerasan dalam

${ }^{14}$ Dalai Lama yang merupakan biksu agama budha pernah berucap: "The whole purpose of religion is to facilitate love and compassion, patience, tolerance, humility, and forgiveness"' (Maksud semua agama adalah untuk memfasilitasi cinta dan kasih sayang, kesopanan, toleransi, kemanusiaan dan memaafkan). Dalam narasi sejarah peradaban manusia, wajah agama sering kali menampakkan roman yang tidak ramah. Tidak dapat dipungkiri, banyak konflik terjadi karena gesekan dan benturan antar agama. Tidak terhitung pula korban manusia yang tumbal atasnya. Jika sudah begini, muncul pertanyaan benarkah agama mengajarkan kebaaikan untuk manusia? Terkhusus dalam agama Islam, Nabi Muhammad SAW mendakwahkan Islam sebagai raḥmatan li al- ‘alamīn, Islam hadir dalam kehidupan pembawa kedamaian dan kasih sayang bagi manusia dan alam. Namun, jika umat Islam tampil dengan mengangkat pedang, meyimpan bom di dalam tas atau mencurigai bahkan mengusir tetangga, benarkah ada kedamaian dan kasih sayang di dalamnya? Barangkali logika pertanyaan tersebut tidak dapat diterima oleh sebagian kalangan. Akan tetapi, setiap manusia berhak untuk mengajukan pertanyaan dan boleh jadi tidak terhindarkan. Dalam perspektif korban konflik kekerasan yang dipicu masalah keagamaan, bagaimana psikologi anak yang kehilangan orang tuanya? Bagaimana perkembangan anak yang mengalami pengusiran dari tempat tinggalnya? Bagaimana perkembangan anak yang mengalami tindak kekerasan? Pada kenyataannya manusia adalah pribadi yang berpikir dan bertindak berdasarkan referensi pengetahuan dan pengalaman. Apabila seorang anak pada masa kecil punya pengalaman buruk berkaitan dengan suatu agama, bagaimanakah ketika dewasa? Tidak menutup kemungkinan individu tersebut menyimpan luka mendalam dan cara pandang yang buruk terhadap suatu agama. Demikianlah konflik kekerasan akan menjadi lingkaran setan yang tanpa ujung pangkal, turun-temurun dari generasi ke generasi. Lingkaran setan konflik kekerasan berlatar belakang agama tidak akan terburai putus jika agama masih menjadi realitas langit yang tidak membumi. Maka, perlu kebijakan dan kearifan untuk mengimplementasikan ayat-ayat dalam kitab suci demi kemaslahatan umat tanpa mengurangi esensi dari keimanan. Lihat Syaiful Arif, Humanisme Gus Dur: Pergumulan Islam dan Kemanusiaan, (Yogyakarat: Ar-Ruzz Media, 2013), 5-6.

Semua agama pasti menganjurkan kejujuran. Nabi Muhammad SAW bersabda: "Yang paling ringan dalam beragama Islam adalah membaca shahadat atau bersaksi bahwa tidak ada Tuhan selain Allah dan Nabi Muhammad adalah Rasulullah. Sedang yang paling berat ialah hidup jujur (dapat dipercaya). Sesungguhnya tidak ada agama bagi orang yang tidak jujur. Bahkan tidak ada shalat dan tidak ada zakat bagi mereka yang tidak jujur" (Hadith riwayat Ahmad Bazzar). Anas RA berkata: "Dalam hampir setiap khatbahnya, Rasulullah selalu berpesan tentang kejujuran. Beliau berpesan: "Tidak ada iman bagi orang yang tidak jujur. Tidak ada agama bagi orang yang tidak konsisten memenuhi janji." Tentu agama lain juga mengandung ajaran sama tentang pentingnya kejujuran dalam kehidupan. Masalahnya, bagaimana kita bisa menanamkan keasadaran tentang pentingnya kejujuran itu. Umat Islam yang selalu menyatakan akan meneladani perilaku Rasulullah ternyata banyak yang hanya meneladani aspek hablun minalläh saja, 
Hindu, kesederhanan dalam Budha dan lain-lain. Dimana itu bukanlah representasi jargon teologis yang tidak dinamis yang kemudian dialih bahasakan ke dalam hukum positif, akan tetapi penerapan nilai-nilai agama yang disublimasikan dari pesan adab subtansial itulah yang menjadi acuan.

Keempat, politik kekuasan $^{16}$, dimana dalam politik ini tampaknya politik hanyalah sebatas alat untuk menggapai kekuasan semata dan upaya untuk menyejahterakan rakyat hanyalah pemanis yang tanpa makna. Untuk macam yang terakhir ini ternyata sering kali membuat masyarakat sebal, karena unsur kesejahteraan bagi seluruh rakyat terabaikan. Dalam tinjauan negara kesejahteraan (welfare state) tentunya hal ini harus dihindari.

\section{Pancasila Sebagai Falsafah Negara}

Pancasila dalam pengertian (asas negara pancasila) sering disebut dasar falsafah negara (filosofische gronslag), ideology negara (staatidee). Dalam hal ini pancasila digunakan sebagai dasar mengatur pemerintahan negara atau dengan kata lain

tetapi sering lupa meneladani beliau dalam aspek hablun minannās. Lihat Salahuddin Wahid, "Pejabat Jujur Sulit Dicari”, Kompas (Maret 2013), 7.

${ }^{15}$ Islam sebagai agama samawi yang komponen dasarnya akidah dan shari'ah, punya kolerasi erat dengan politk dalam arti yang luas. Sebagai sumber motivasi masyarakat, Islam berperan penting menumbuhkan sikap dan perilaku sosial politik. Implementasinya kemudian diatur dalam shari'ah, sebagai katalog lengkap dari perintah dan larangan Allah, pembimbing manusia, dan pengatur lalu lint as aspekaspek kehidupan manusia yang kompleks. Islam dan politik mempunyai titik singgung erat, bila keduanya dipahami sebagai sarana menata kebutuhan hidup manusia secara menyeluruh. Islam tidak hanya dijadikan kedok untuk mencapai kepercayaan dan pengaruh dari masyarakat semata. Politik juga tidak hanya dipahami sekadar sebagai sarana menduduki posisi otoritas formal dalam struktural kekuasaan. Lihat MA. Sahal Mahfudh, Nuansa Fiqh sosial (Yogyakarta: LKiS, 2011), 213.

${ }^{16}$ Sayangnya yang lebih banyak muncul dipermukaan panggung perpolitikan mulai zaman purba hingga sekarang hanyalah politik kekuasan, dimana politik hanyalah digunakan sebagai alat (instrumen) untuk mencapai kursi jabatan yang empuk sehingga bila kita cermati bersama politik bukanlah sebagai maqāsid (perantara) untuk mewujudkan kesejahteraan sosial (social welfare). Sebuah pemandangan yang menyayat hati. Dalam hal ini, bila politik bekawin-mawin dengan kekuasaan, lantas berkembang biak melahirkan lubang hitam atau lubang buaya juga bisa, maka dalam hal ini yang muncul adalah tindak korup yang membuat pejabat bersuka cita dan membuat rakyat menderita. 
pancasila digunakan sebagai dasar untuk mengatur penyelenggaraan negara. ${ }^{17}$

Pengertian pancasila sebagai dasar negara seperti dimaksudkan di atas sesuai dengan bunyi pembukaan UUD 1945, yang menyatakan ${ }^{18}$ :

“....maka disusunlah kemerdekaan kebangsaan Indonesia itu dalam suatu undang-undang dasar yang berbentuk dalam suatu susunan negara Indonesia yang berkedaulatan rakyat dengan berdasarkan kepada..."

Dipandang dari segi morfologi bahasa Indonesia, kata berdasar berasal dari kata dasar, yang diberi awalan ber-menjadi berdasar. ${ }^{19}$

Dari sudut sejarah, pancasila sebagai dasar negara pertamatama diusulkan oleh Ir. Soekarno pada siding Badan Penyelidik Usaha-usaha Persiapan Kemerdekaan Indonesia (BPUPKI) dalam rapatnya mencari fhilosofhisce grosnlag untuk Indonesia yang merdeka, maka diputuskanlah pancasila sebagai dasar negara. ${ }^{20}$ Sejak saat itu pula pancasila digunakan sebagai nama dari falsafah negara dan pandangan hidup bangsa Indonesia, meskipun untuk itu terdapat beberapa tata urut dan rumusan yang berbeda. Sejarah rumusan pancasila itu tidak dapat dipisahkan dengan sejarah perjuangan bangsa Indonesia dan tidak dapat pula dipisahkan dari sejarah perumusan UUD $1945 .^{21}$

Pancasila sebagai dasar negara, hal ini berarti bahwa setiap tindakan rakyat dan negara Indonesia harus sesuai dengan

17 Titik Triwulan Tutik, Kontruksi Hukum Tata Negara Indonesia Pasca Amandemen UUD 1945, (Jakarta: Kencana, 2011), 78.

${ }^{18}$ Ibid.

${ }^{19}$ Ibid.

${ }^{20}$ Pada masa akhir kolonianisme, muncul perdebatan mengenai (konstitusi) dasar negara. Sebagian mereka ada yang menginginkan agar dasar negara Indonesia adalah Islam, sementara yang lain mengehendaki agar dasar negara Indonesia nasionalis (sekuler). Perdebatan tentang dasar negara mulai memanas pada bulanbulan menjelang proklamasi kemerdekaan Indonesia, 17 Agustus 1945. Ditengah perdebatan tentang bentuk negara, menurut Andree Feillard, berangkat dari hasil urun-rembuk dengan tiga tokoh kenamaan muslim, Kiai Wahid Hasyim, Kiai Maskur -keduanya dari NU- dan Kiai Kahar Muzakkar dari PII-, pada tanggal 1 Juni 1945, Soekarno berupaya mengatasi persoalan tersebut dengan mengajukan "lima dasar" atau pancasila sebagai landasan filosofis Indonesia. Lihat Chafid Wahyudi, NU\& Civil Religion: Melacak akar civil religion dalam keagamaan NU, (Yogyakarta: Graha Ilmu, 2013), 80.

${ }^{21}$ Titik Triwulan, Kontruksi Hukum......., 78. 
pancasila yang sudah ditetapkan sebagai dasar negara tersebut. ${ }^{22}$ Hal ini mengingat bahwa pancasila digali dari budaya bangsa Indonesia sendiri, sehingga pancasila mempunyai fungsi dan peranan yang sangat luas dalam kehidupan bermasyarakat, berbangsa dan bernegara. ${ }^{23}$

Pancasila $^{24}$ dipandang sebagai dasar negara Indonesia karena di dalamnya mengandung beberapa asas (lima asas) yang dapat dilihat sebagai berikut: ${ }^{25}$

22 Kalau Nabi dahulu merupakan pemimpin tunggal dengan otoritas yang berlandaskan kenabian dan bersumberkan wahyu, serta bertanggung jawab atas segala tindakan beliau kepada Tuhan semata, maka tidaklah demikian posisi khalifah pengganti beliau. Hubungan mereka dengan rakyat atau umat berubah menjadi hubungan antara dua peserta dari suatu kesepakatan atau "kontrak sosial" yang memberikan kepada masing-masing hak dan kewajiban atas dasar timbal balik, seperti yang tercermin dalam baiat yang disusul dengan "pidato pengukuhan". Kiranya dapat dikatakan bahwa para khalifah dan rakyat itu masingmasing terikat oleh kesepakatan dua tingkat. Pada tingkat pertama kedua belah pihak bersepakat hendak tetap dan terus melaksanakan ajaran Islam sebagaimana yang diwariskan oleh Nabi. Kemudian pada tingkat selanjutnya kedua belah pihak bersepakat hendak melestarikan dan mempertahankan kehidupan bernegara yang telah dirintis oleh Nabi. Dalam hal itu rakyat mempercayakan pengelolaan urusan mereka kepada para khalifah disertai janji kesetiaan. Sebaliknya, para khalifah menjamin terus tegaknya Islam dan keamanan jiwa, keluarga dan harta benda rakyat, serta betanggung jawab atas kesejahteraan umum. Lihat Munawir Sjadzali, Islam Dan Tata Negara: Ajaran, Sejarah dan Pemikiran, (Jakarta: UI Press, 1993), 31. Dalam konteks ke-Indonesiaan tentunya yang terjadi adalah "kontrak sosial" antara presiden dan rakyat, dimana dalam hal ini presiden dituntut untuk menjaga terus tegaknya pancasila yang didalamnya terkandung nuansa atau nilai-nilai Islami, sehingga terwujudlah keamanan jiwa, keluarga dan harta benda rakyat, serta muncullah kesejahteraan umum.

${ }^{23}$ Titik Triwulan, Kontruksi Hukum ....., 79.

${ }^{24}$ Majalah mingguan Hikmah terbitan 9 Mei 1954 memuat tulisan Natsir berjudul: "Bertentangankah Pancasila dengan Al-Qur'an". Dalam tulisan itu dia membandingkan tiap sila dari pancasila dengan ajaran al-Qur'an. Dia bertanya mana mungkin Al-Qur'an yang memancarkan tauhid dapat apriori bertentangan dengan sila Ketuhanan Yang Maha Esa? Mana mungkin Al-Qur'an yang ajarannya penuh kewajiban menegakkan 'adālah ijtima'iyyah dapat apriori dengan bertentangan dengan sila keadilan sosial? Mana mungkin Al-Qur'an yang justru memberantas sistem feodalisme dan pemerintah istibdād (dikatator) sewenangwenang, serta meletakkan dasar musyawarah dalam susunan pemerintah, dapat bertentangan dengan apa yang dinamakan dengan kedaulatan rakyat? Mana mungkin Al-Qur'an yang menegakkan istilah islāh bainannas (damai antara manusia) dapat apriori bertentangan dengan apa yang disebut Peri Kemanusiaan? Mana mungkin Al-Qur'an yang mengakui adanya bangsa-bangsa dan meletakkan dasar yang sehat bagi kebangsaan, dapat apriori bertentangan dengan kebangsaan. 
1. Asas Ketuhanan Yang Maha Esa

Di dalam pembukaan UUD 1945 alinea ke IV disebutkan, “...maka disusunlah kemerdekaan kebangsaan Indonesia itu dalam suatu UUD Indonesia yang berkedaulatan rakyat dengan berdasarkan ketuhanan Yang Maha Esa."26

Realisasi dari asas ketuhanan Yang Maha Esa tercermin dalam tiga bidang ketatanegaraan republik Indonesia antara lain:

a) Dalam bidang eksekutif, dengan adanya departemen Agama dan segala bagian-bagiannya yang mengatur segala soal yang menyangkut agama di Indonesia;

Lihat Munawir Syadzali, Islam Dan Tata Negara: Ajaran, Sejarah Dan Pemikiran, (Jakarta: UI Press, 1993), 195.

${ }^{25}$ Ibid.

${ }^{26}$ Sesaat setelah proklamasi kemerdekaan pada tanggal 18 Agustus 1945, Moh. Hatta memanggil empat anggota panitia persiapan kemerdekaan Indonesia yang dianggap mewakili Islam: Ki Bagus Hadikusumo, Kasman Singodimedjo, Teuku Muhammad Hasan dan Wahid Hasyim. Demi menjaga keutuhan bangsa pada saat genting ini, mereka setuju untuk menghapuskan rujukan pada agama Islam dari naskah pembukaan UUD 1945. Sebagai gantinya Wahid Hasyim mengusulkan agar piagam Jakarta diganti dengan rumusan "Ketuhanan yang Maha Esa" yang semula hanya "kepercayaan kepada Tuhan". Nampak bahwa usulan tersebut mendekatkan sila pertama pancasila dengan doktrin sentral umat Islam, yaitu doktrin tauhid, pengakuan atas kemahatunggalan Tuhan. Di situ letak pemikiran ulung dari kader NU, Wahid Hasyim yang mampu mengakomodir keberagaman di dalam satu negara. Bagi umat Islam, arti yang penting inti dari sila pertama tentang kepercayaan terhadap "Tuhan Yang Maha Esa" justru adalah aqidah Islam. Dengan penerimaan pancasila yang demikian, merupakan pelaksanaan secara nyata ajaranajaran shari'ah sesuai dengan cita-cita Islam. Di sisi yang lain adalah tidak sepenuhnya benar jika kepercayaan terhadap "Tuhan Yang Maha Esa" berimplikasi tidak terdapat pada agama lain sebagaimana dikemukakan Deliar Noer yang kemudian kerap dikutip oelh penulis-penulis berikutnya seperti Andree Feillard, Robert W Hafner dan lain-lain. Sebab secara teoritis, semenjak ribuan tahun yang lalu masyarakat sudah percaya akan adanya satu kekuatan gaib yang melampaui kekuatan manusia. Kekuatan gaiblah itulah yang dipahami sebagai Tuhan. Pemahaman terhadap satu kekuatan gaib itu yang kemudian disimbolisasikan ke dalam benda-benda di alam sekitarnya. Benda-benda itu dianggap sebagai Tuhan yang hadir ke dunia. Tuhan dimengerti dapat menampakkan diri-Nya dalam berbagai rupa di alam raya ciptaan-Nya yang disebut; tajalli al-Shuhud (penampakan diri). Penampakan diri Tuhan yang tertinggi ada pada makhluk ciptaan-Nya yang berwujud manusia, demikianlah Muhyiddin Ibnu Arabi berfilsafat dalam dunia mistiknya. Oleh karena itu, agama selain Islam juga menyembah yang Esa (oer-monoteisme). Lihat Chafid Wahyudi, $N U \&$ Civil Religion: Melacak akar civil religion dalam keagamaan NU, (Yogyakarta: Graha Ilmu, 2013), 81. 
b) Dalam bidang legislatif tercermin pelaksanaannya dalam UU No.1 Tahun 1974 tentang UU perkawinan;

c) Dalam bidang Yudikatif, tertuang dalam UU No.14 Tahun 1970 yang telah diubah melalui UU No.4 tahun 2004 tentang kekuasaan kehakiman pada pasal 4 Ayat (1) disebutkan bahwa peradilan dilakukan, "Demi keadilan berdasarkan ketuhanan yang Maha Esa", dan ini tercermin dalam setiap keputusan peradilan umum di Indonesia. Begitu pula dengan adakalanya peradilan agama yang khususnya diadakan bagi yang beragama Islam, adalah realisasi dari dari sila ketuhanan yang Maha Esa. ${ }^{27}$

2. Asas Perikemanusiaan

Asas perikemanusiaan ${ }^{28}$ adalah asas yang mengakui dan memperlakukan manusia sesuai dengan harkat dan martabatnya sebagai makhluk Tuhan, juga mengakui persamaan derajat, persamaan hak dan kewajiban asasi manusia tanpa membedabedakan suku, keturunan, agama, ras, warna kulit kedudukan sosial, dan lain-lain. ${ }^{29}$

Di dalam pembukaan UUD 1945 dan juga pasal 34 adalah merupakan perwujudan dari asas perikemanusiaan dalam hukum positif Indonesia dalam kehidupan sehari-hari hal ini terlihat pada lembaga-lembaga yang didirikan untuk menampung segala yang tidak seimbang dalam kehidupan sosial. Contohnya, panti asuhan untuk anak yatim piatu, anak cacat dan manula atau lansia. ${ }^{30}$

Dari segi legislatif dapat dilihat dari lahirnya UU Perburuan yang menghilangkan prinsip pengisapan manusia oleh manusia.

${ }^{27}$ Titik Triwulan, Kontruksi Hukum ......., 79.

28 Membaca (memahami) asas perikemanusiaan berarti membaca HAM, bila ditelusuri, Human Rights atau Hak-hak Asasi Manusia (HAM) adalah istilah yang relatif baru, namun ia telah menjadi kepedulian etis utama masa kini. Pada dasarnya HAM berawal pada konsep kuno Yunani-Romawi yang mengkaitkan sikap manusia serta mengukur baik-buruknya berdasarkan keserasiannya dengan hukum alam. Konsep ini, yang dikenal dengan natural law doctrine (doktrin hukum alam), lebih menekankan kepada kewajiban daripada hak. Sejak masa Renaisans (sekitar abad 15) sampai masa kini, paling tidak dalam konteks dunia barat sekuler, penekanan terhadap kewajiban-kewajiban manusia dalam kerangka hukum alam berlaih kepada hak-hak manusia. Lihat Alwi Shihab, Islam Inklusif: Menuju Sikap Terbuka Dalam Agama, (Bandung: Mizan, 1999), 177.

${ }^{29}$ Titik Triwulan, Kontruksi Hukum ......, 79.

${ }^{30}$ Ibid., 80 . 
Dalam bidang eksekutif terbentuknya Departemen sosial yang menanggulangi masalah-masalah kemanusiaan. Contohnya, Direktorat Bencana Alam yang memberikan bantuan bagi masyarakat yang tertimpa musibah bencana alam dan sebagainya. ${ }^{31}$

3. Asas Kebangsaan

Dalam asas kebangsaan setiap warga negara mempunyai kedudukan, hak dan kewajiban yang sama. Asas ini menunjukkan, bahwa bangsa Indonesia bebas menentukan nasibnya sendiri dan berdaulat yang berarti pula bahwa bangsa Indonesia tidak membolehkan adanya campur tangan (intervensi) dari bangsa lain dalam hal mengenai urusan dalam negeri. $^{32}$

Asas kebangsaan tertuang pula dalam simbol atau lambang negara republik Indonesia, yaitu garuda pancasila (pasal 36A), bendera kebangsaan yaitu sang saka merah putih (pasal 35), bahasa persatuan 'bahasa Indonesia' (pasal 36), lagu kebangsaan 'Indonesia Raya' (pasal 36B) dan lambing persatuan dan kesatuan 'Bhineka Tunggal Ika' (pasal 36B). ${ }^{33}$

Di samping itu asas kebangsaan termuat dalam pembukaan alinea pertama dan pasal-pasal UUD 1945. Sebagai contoh dalam mewujudkan pasal 33 UUD 1945, bahwa bumi, air dan kekayaan alam yang terkandung didalamnya dikuasai oleh negara dan digunakan untuk kepentingan rakyat. Hal ini sama juga dalam rangka perlindungan bangsa terhadap kemungkinan pengaruh buruk dari luar negeri dan juga perlindungan terhadap orang asing yang ada di Indonesia demi kepentingan bangsa. ${ }^{34}$

Di bidang legislatif asas ini terlihat dengan lahirnya UU Kewarganegaraan (UU No.5 1960) yang berkaitan langsung dengan kepentingan rakyat. ${ }^{35}$

Aplikasi asas kebangsaan dalam pengadilan berupa keputusan, apabila terjadi perselisihan antar warga negara Indonesia dan warga negara asing, di Indonesia dimana yang berlaku adalah undang-undang Indonesia. ${ }^{36}$

\footnotetext{
Ibid.

${ }^{32}$ Ibid.

33 Ibid.

${ }^{34}$ Ibid.

${ }^{35}$ Ibid., 81.

${ }^{36}$ Ibid.
} 
4. Asas Kedaulatan Rakyat

Asas kedaulatan rakyat ${ }^{37}$ dalam bidang legislatif merupakan perwujudan dari kedaulatan rakyat ada wewenang yang dimiliki DPR. Sedangkan dalam yudikatif terlihat bahwa hakim-hakim baru dapat diangkat setelah ada pengusulan dari Komisi Yudisial kepada anggota DPR untuk mendapat penetapan yang selanjutnya diangkat oleh presiden. ${ }^{38}$

Dalam pembukaan UUD 1945 asas ini tertuang dalam alinea IV yang menyatakan, "Maka disusunlah kemerdekaan kebangsaan Indonesia itu dalam UUD negara Indonesia yang berkedaulatan rakyat... ${ }^{39}$

Asas kedaulatan rakyat mengehendaki agar setiap tindakan dari pemerintahan harus berdasarkan kemauan rakyat, yang pada akhirnya semua tindakan pemerintah harus dapat dipertanggungjawabkan kepada rakyat melalui wakil-wakilnya. Hal ini dapat dilihat dari pelaksanaannya dari ketetapan MPRS No. XIII/MPR No. VI/MPR/1973. ${ }^{40}$

Penjelmaan dari ketetapan ini dapat dilihat pada persetujuan dari rakyat atas tindakan pemerintah itu dapat ditunjukkan bahwa Presiden tidak dapat menetapkan suatu peraturan pemerintah, tetapi terlebih dahulu adanya UU artinya tanpa persetujuan rakyat Presiden tidak dapat menetapkan suatu

\footnotetext{
${ }^{37}$ Pada zaman Renaissance, timbul teori yang mengajarkan bahwa dasar hukum itu adalah akal atau rasio manusia (aliran rasionalisme). Menurut aliran Rasinalisme ini, bahwa raja dan penguasa negara lainnya memperoleh kekuasaannya itu bukanlah dari Tuhan, tetapi dari rakyatnya. Pada abad pertengahan diajarkan, bahwa kekuasaan raja itu berasal dari suatu perjanjian antara raja dengan rakyatnya yang menaklukkan dirinya kepada raja itu dengan syarat-syarat yang disebutkan dalam perjanjian itu. Kemudian setelah itu dalam abad ke-18 Jean Jacques Rousseau memperkenalkan teorinya, bahwa dasar terjadinya suatu negara ialah "perjanjian masyarakat" (contract social) yang diadakan oleh dan antara anggota masyarakat untuk mendirikan suatu negara. Adapun teori Rousseau tersebut dikemukakannya dalam buku karangannya yang berjudul "le contrat social"(1762). Teori Rousseau yang menjadi dasar paham "kedaulatan rakyat" mengajarkan, bahwa negara bersandar atas kemauan rakyat tersebut. Demikian menurut aliran ini, bahwa hukum itu adalah kemauan orang seluruhnya yang telah mereka serahkan kepada suatu organisasi (yaitu negara) yang telah terlebih dahulu mereka bentuk dan diberi tugas membentuk hukum yang berlaku dalam masyarakat. Orang mentaati hukum, karena orang sudah berjanji mentaatinya. Lihat Kansil, Pengantar Ilmu Hukum Dan Tata Hukum Di Indonesia, (Jakarta: Balai Pustaka, 1986), 62.

${ }^{38}$ Titik Triwulan, Kontruksi Hukum ...., 81.

${ }^{39}$ Ibid.

${ }^{40}$ Ibid., 82.
} 
peraturan pemerintah. Dan akhirnya Presiden harus memberikan pertanggungjawabannya kepada MPR yang merupakan penjelmaan dari rakyat Indonesia yang memegang kedaulatan rakyat. $^{41}$

Asas kedaulatan rakyat ini semakin memperoleh ruhnya, dalam era reformasi dengan dilaksanakan pemilu secara langsung sebagaimana disebutkan dalam UU No.12 Tahun 2004 tentang pemilu Anggota DPR dan DPRD dan UU No. 24 Tahun 2004 tentang pemilu Presiden dan wakil presiden. ${ }^{42}$

5. Asas Keadilan Sosial

Dalam bidang legislatif, asas keadilan sosial pelaksanaannya tertuang dalam rangka mewujudkan undang-undang tentang jaminan sosial. Misalnya adanya pusat-pusat industri yang memungkinkan timbulnya perselisihan atau sengketa antara pihak pemimpin dan pihak buruhnya, yang perlu adanya suatu badan yang akan menyelesaikan sengketa itu tidak secara sepihak dan sewenang-wenang, melainkan dengan berpedoman kepada keadilan sosial yang selalu memperhitungkan nasib kaum buruh tersebut. ${ }^{43}$

Dalam bidang yudikatif terlihat bahwa setiap keputusan hakim senantiasa berpedoman kepada keadilan sosial. Adapun dalam bentuk lembaga terlihat adanya lembaga negara yang bergerak di bidang sosial yang menyelenggarakan masalahmasalah sosial dalam negara. ${ }^{44}$

\section{Hukum Sebagai Aturan Yang Mengikat}

Hukum $^{45}$ adalah rangkain peraturan-peraturan mengenai tingkah-laku orang-orang sebagai anggota suatu masyarakat, yang bersifat memaksa, untuk mengadakan tata tertib diantara anggotaanggota masyarakat dalam rangka melindungi kepentingankepentingan orang dalam masyarakat itu. ${ }^{46}$

\footnotetext{
41 Ibid.

${ }^{4}$ Ibid.

${ }^{43}$ Ibid.

${ }^{44}$ Ibid., 83.
}

${ }^{45}$ Hukum sebagai kaidah, pada dasarnya menempatkan hukum sebagai pedoman yang mengatur kehidupan dalam bermasyarakat agar tercipta ketentraman dan ketertiban bersama. Lihat Titik Triwulan Tutik, Pengantar Ilmu Hukum, (Jakarta: Prestasi Pustaka), 26.

${ }^{46}$ Sjechul Hadi Pernomo, "Relevansi Filsafat Hukum Nasional Dan Filsafat Hukum Islam: Suatu Tinjauan Komparatif”, Akademika, Vol.14 ,No.2, (Maret, 2004), 121. 
Konsep negara hukum pancasila meletakkan pancasila sebagai sumber dari segala sumber yang berlaku di negara Republik Indonesia dan dengan sistem konstitusionalnya, meletakkan UUD 1945 sebagai hukum dasar dan merupakan sumber hukum yang kedua setelah pancasila. ${ }^{47}$

Setiap produk hukum, seperti undang-undang, peraturan atau keputusan pemerintah, bahkan juga setiap tindakan kebijaksanaan pemerintah haruslah berlandaskan dan bersumberkan pada peraturan yang lebih tinggi, yang akhirnya dapat dipertanggung jawabkan pada ketentuan-ketentuan UUD $1945 .{ }^{48}$

Dalam kedudukan yang demikian itu, UU Dasar dalam kerangka tata-urutan atau tata-tingkatan norma hukum yang berlaku merupakan hukum yang menempati kedudukan tertinggi. Dalam hubungan ini, Undang-Undang Dasar. Oleh karena itu peraturan hukum atau perundang-undangan yang tingkatannya lebih rendah tidak boleh bertentangan bertentangan dengan peraturan hukum atau peraturan perundang-undangan yang tingkatannya lebih tinggi dan apabila sampai terjadi pertentangan, maka yang dimenangkan adalah peraturan hukum atau peraturan perundang-undangan yang lebih tinggi tingkatannya. ${ }^{49}$

Dalam batang tubuh UUD 1945 terdapat 7 pasal yang mengatur langsung hak asasi manusia. Meskipun hanya 7 pasal, namun pasal-pasal tersebut merupakan hal-hal pokok. ${ }^{50}$

Pasal 27, mengenai hak tentang persamaan dalam hukum dan penghidupan yang layak bagi kemanusiaan.

Pasal 27 Ayat (1) menyebutkan bahwa segala warga negara bersamaan kedudukan dalam hukum. Prinsip persamaan di dalam hukum ini hampir sama dengan prinsip equality before the law, yang berarti bahwa tidak ada perbedaan warga, terbuka setiap warga negara yang memenuhi persyaratan untuk itu.

Pasal 27 (2) mengehendaki bahwa negara berhak atas penghidupan yang layak bagi manusia. Karenanya adalah kewajiban pemerintah untuk menciptakan lapangan pekerjaan baru yang layak bagi manusia.

Pasal 28 tentang kebebasan berserikat, berkumpul dan mengeluarkan pikiran secara lisan maupun tulisan. Ketiga hak

\footnotetext{
47 Ibid.

${ }^{48}$ Ibid.

49 Ibid.

${ }^{50}$ Titik Triwulan, Kontruksi Hukum 296.
} 
asasi ini adalah hak-hak yang sangat penting dalam negara demokrasi. $^{51}$ Kebebasan berserikat tidak akan ada artinya jika

51 Lebih dari 50 tahun sesudah proklamasi kemerdekaan Republik Indonesia, perwujudan kenegaraan demokratis tetap merupakan agenda yang masih di depan kita. Keberhasilan pemerintah Orde Baru dalam bidang pembangunan ekonomi, perwujudan adminitrasi kenegaraan dan politik luar negeri tidak dibarengi keberhasilan dalam pembangunan kehidupan demokratis. Ciri khas suasana politik dalam pemerintahan Orde Baru adalah pendekatan top down. Kebijakan massa mengambang, penataan kembali kehidupan kepartaian, domestikasi pemilihan umum, gaya pelaksanaan sidang umum MPR, lemahnya fungsi DPR, menyusutnya ciri-ciri negara hukum menjadi negara kekuasaan, kekhawatiran tak proporsional alat-alat negara terhadap pertemuan, rapat, seminar yang bernada kritis: semua itu dan banyak unsur lain telah menciptakan suasana yang segala-galanya tergantung dari koneksi dengan penguasa. Bukan seakan-akan defisit demokrasi sama sekali tidak disadari. Pasang surut gelombang keterbuakaan dan ketertutpan membuktikan bahwa pemerintah pun samar-samar merasa bahwa belum semuanya beres dalam struktur-struktur kekuasaan politik di negara kita. Tetapi sampai sekarang pola usaha-usaha peningkatan keterbukaan bersifat on-off dan bukan off-on. Seakan-akan sudah menjadi nasib bahwa setiap gelombang keterbukaan berakhir dalam ketertutupan lagi. Lihat Franz Magnis Suseno, Kedaulatan Rakyat, Bukan Kedaulatan Tuan, Kata Pengantar dalam Muhammad AS Hikam, Demokrasi Dan Civil Society (Jakarta: LP3ES, 1999 ), xii.

Harus diakui derap demokrasi kita selama 15 tahun diera reformasi berjalan sangat lamban. Meski demikian, apa yang telah dicapai oleh bangsa ini semestinya menjadi semacam tonggak dalam mengidentifikasi dan menyempurnakan cela-cela demokrasi kita. Dalam konteks ini, 2014 adalah tahun pertaruhan bagi kualitas demokrasi kita. Jika demokrasi hanya dipahami sebatas perebutan kuasa di medan politik, dipastikan kualitas demokrasi mengalami stagnasi. Inilah bentuk pendangkalan demokrasi paling klasik: demokrasi dibajak para gerombolan yang hanya mencari peruntungan belaka. Sebaliknya, jika demokrasi dipahami dan dipraktikkan sebagai keseluruhan sistem bernegara-bangsa menuju sebuah tatanan kehidupan yang lebih baik, beradab, dan sejahtera lahir batin, barulah peningkatan demokrasi dapat diarasakan. Lihat Masdar Hilmy, "Banalitas Demokrasi Kita", Kompas (24 Januari,2014), 7.

Selanjutnya ketidakjelasan identitas kebangsaan dan "jenis kelamin" demokrasi kita sekarang ini sejatinya disebabkan oleh ketidakjelasan visi-misi Indonesia di atas. Konsep demokrasi yang dipahami dan dipraktikkan di jagat politik kita tidak lain adalah kohabitasi konfliktual antara dua entitas yang oksimoronik: demokrasi dan plutokrasi, demokrasi dan politik uang, demokrasi dan (neo) patrimonialisme, demokrasi-oligarki, dan semacamnya. Lihat Masdar Hilmy, "Demokrasi Roller Coaster", dalam http://WWW. uinsby.ac.id/index.php/19-uinsa/kolomakademisi/119-demokrasi-roller-coas ter.

Kiranya butuh pergeseran pandangan dari demokrasi lama yang involutif menuju demokrasi yang lebih subtantif. Manakala demokrasi yang lebih subtantif bisa terealisasikan, bukan tidak mungkin ke depannya Indonesia akan semakin baik dan maju. Pada sisi ini sebenarnya urgensi negara untuk mengembangkan demokrasi substantif yang tidak sekadar terpaku pada prosedur dan simbol formal. 
Oleh karena inti demokrasi adalah rakyat dan keadilan, serta kesetaraan, maka ranah publik seutuhnya milik mereka yang harus disikapi dan dikelola secara terbuka dan secara adil secara bersama-sama. Transparansi menjadi salah satu inti dari demokrasi karena tanpa itu ruang publik yang sejatinya milik dan menjadi tanggung-jawab rakyat hanya akan bersifat semu. Pada gilirannya keterbukaan menuntut adanya kejujuran, tanggung jawab, keadilan, dan etika-moral sejenis dari semua pihak, termasuk dari masyarakat sendiri. Tanpa semua itu, masyarakat akan menjadi obyek dari kepentingan orang dan kelompok tertentu, serta pada saat yang sama masyarakat tidak akan pernah menjadi dewasa. Kejahatan yang merugikan negara dan rakyat dimungkinkan akan terus berlangsung. Pada saat yang sama, keterbukaan akan mengantarkan seorang yang selama ini dikenal akan integritas kepribadiannya berupaya dengan konsisten untuk menjaga etika-moral yang disandangnya. Sebab ketika ada peluang untuk menyimpang, masyarakat akan mengetahui dan melakukan kontrol sedini mungkin. Pembumian nilai-nilai demokrasi substantif akan menjadikan moral sebagai sistem yang tidak hanya bersifat personal, tapi juga institusional. Itulah agenda yang perlu dikembangkan secara sungguh-sungguh ke depan dan perlu dilabuhkan ke dalam realitas nyata kehidupan bangsa. Lihat Abd A'la, "Mewaspadai Penyalahgunaan Kekuasaan" dalam http://WWW.uinsby.ac.id/index.php/19-uinsa/kolom-akademisi/113-pengguna an-kekuasaaan-signifikansi-substantif.

Menghayati terwujudnya penyimpangan akan demokrasi sebagai sistem luhur bagi manusia kontemporer di jagad raya ini, mengantarkan pada pemahaman, bahwa penyimpangan bukanlah hal yang ramah yang menyebabkan sebagian manusia kontemporer non-karikatif, apalagi kreatif dalam mendayagunakan nalar sehat. Alih-alih berusaha untuk membahagiakan diri sendiri dan kelompoknya, justru secara nalar sehat mereka terperangkap dalam pengesampingan nalar kebangsaan. Lebih lanjut manakala hal itu terjadi, bisa dipastikan akan terjadi guncangan (disruption) yang memunculkan tidak adanya kohesi sosial, sehingga nilai-nilai humanis yang diungkapkan oleh mereka ke ranah publik menjadi hipokrit belaka. Sejatinya, relasi demokrasi yang bernuana pembebasan dengan manusia yang dalam hal ini merupakan objek yang dilalimi, hendaknnya didasarkan pada mutu relasi yang berimplikasi pada kebajikan bersama. Pada sisi tersebut nalar sehat menjadi media yang paling efektif dan urgen untuk mengontrolnya. Begitu juga, manakala kebajikan bersama yang mengantarkan pada kesejahteraan dan keadilan bersama telah berjalin-kelindan dengan manusia, maka pembumian demokrasi bisa dirasakan secara lahir-batin, karena demokrasi telah mengalami peningkatan secara tajam. Di sinilah fungsinya pembumian demokrasi substansial, sebagai wahana pendayagunaan nalar sehat. Bila demokrasi lebih berorientasi pada kebebasan an sich dan pada saat yang bersamaan nilai-nilai humanis terabaikan, maka akan berimplikasi pada dua kemungkinan, yaitu perselingkuhan manusia pemegang kekuasaan dengan demokrasi semu dan terjadinya guncangan yang berimbas pada disintegrasi sosial, karena kohesi sosial terabaikan. Untuk itu dalam menyikapi pengesampingan demokrasi otentik, butuh upaya secara rutin atau berkala untuk membersihkan demokrasi dari tangan-tangan yang tak bertanggungjawab. Ini seperti urusan baju kotor. Manakala baju kotor (terdapat noda) tetap dibiarkan, maka sudah barang tentu baju itu selamanya tak akan bersih. Dari sini kemudian butuh pembersihan secara berkala, supaya baju yang terpakai 
tidak ada kebebasan untuk mengeluarkan pendapat. UUD 1945 sendiri menyebutkan hal itu harus diatur dalam undang-undang. Pemerintah dan DPR menyusun UU No.3 Tahun 1975 sebagai pelaksanaan pasal 28 khususnya kebebasan berserikat (freedom of association) adalah kebebasan untuk mendirikan parpol. Pengakuan terhadap parpol oleh pemerintah tidak boleh dikaitkan dengan program partai tersebut yang akan mendukung atau berposisi dengan pemerintah, jadi partai bebas menentukan sikap.

Pasal 29, tentang kemerdekaan untuk memeluk agama. Pada ayat (2) disebutkan bahwa negara menjamin kemerdekaan tiaptiap penduduk untuk memeluk agamanya masing-masing dan beribadah menurut agamanya. Namun ayat ini ditafsirkan sehubungan ayat (1) yang menyatakan bahwa negara berdasarkan ketuhanan yang Maha Esa. Jadi kebebasan tersebut adalah dalam hubungannya dengan agama yang mempercayai ke-Esaan Tuhan.

Pasal 31 tentang hak untuk mendapatkan pengajaran. Opersionalisasi dari ketentuan ini tertuang dalam UU No.12 Tahun 2003 tentang sistem pendidikan nasional.

Pasal 32 tentang perlindungan yang bersifat kultural.

Pasal 33 tentang haka-hak ekonomi.

Pasal 34 tentang kesejahteraan sosial.

Adalah kesepakatan para ahli hukum bahwa hukum diarahkan terhadap tingkahlaku manusia. Dalam Islam disebut af'āl almukallafin $^{52}$ (tindakan-tindakan orang dewasa). Jadi hukum tidak bisa dirumuskan untuk memutuskan dan menetapkan sesuatu atau hal yang abstrak dan eksklusif. Pada sisi lain hukum ditujukan

tetap terjaga dari noda. Dengan demkian, tak ada salahnya -untuk mengatakan benar dan apa adanya, bahwa otentifikasi demokrasi, menjadi hal layak untuk dikembangkan secara bersama. Hal tersebut merupakan upaya membangkitkan kembali epistemis makna demokrasi yang kian memudar dan seakan-akan kehilangan signifikasinya -dalam hal ini tentunya harus ada perujukan makna asal yang diselaraskan antara bentuk dan substansi demokrasi. Sehingga kepentingan seksional bisa dibendung sebisa mungkin dengan adanya upaya pendayagunaan nalar sehat dalam mengelola pemerintahan. Semoga ke depannya Indonesia semakin membaik.

${ }^{52}$ Pada kenyataannya Mukallafin ialah orang yang dewasa dan berakal yang secara pemahaman tuntutannya tidak terhalang, sebelum adanya mukallaf atau sesuadah adanya mukallaf, sebelum diutusnya Nabi, sedangkan pemenuhan (pelaksanaan) tuntutan ini ialah setelah adanya mukallaf dan setelah diut usnya Nabi, karena tidak ada hukum sebelum diutusnya Nabi, dimana pada waktu itu belum ada kepastian hukum yang berimplikasi pada pahala atau siksa. Lihat Yahya Zakariyah alAnshari, Ghāyah al-Wusūl, (Surabaya: al-Hidayah, tt), 6-7. 
untuk kepentingan manusia. Seorang ahli hukum Islam klasik Izz al-Dīn bin 'Abd al-Salām (w. $660 \mathrm{H}$ ), menyatakan: "Seluruh ketentuan hukum dibuat untuk kepentingan manusia, baik dalam kehidupan di dunia maupun di akhirat. ${ }^{53}$ Ketaatan manusia kepada Tuhan tidak membuat-Nya memperoleh manfaat apapun, dan kedurhakaan manusia tidak menjadikannya merugi apapun." Dengan bahasa lain, pembelaan manusia kepada Tuhan tidak menjadikan Dia lebih agung atau mulia, dan pembangkangan manusia kepada-Nya tidak menjadikan Dia lebih rendah dan kurang mulia. ${ }^{54}$

Para ahli hukum Islam berpendapat bahwa hukum Islam bersumber dari ajaran Islam (Al-Qur'an dan al-Hadith) sehingga biasa disebut law is religion. Selain itu, hukum Islam biasa disebut islamic law dan islamic jurisprudence. islamic law disebut syariat Islam dan islamic jurisprudence disebut fikih. ${ }^{55}$

Shariah dalam pengertian etimologi adalah jalan yang harus ditempuh oleh umat Islam. Shariah dalam pengertian secara terminologi adalah seperangkat norma Ilahi yang mengatur hubungan manusia dengan Allah, hubungan manusia dengan manusia lain dalam kehidupan sosial, hubungan manusia dengan benda dan alam lingkungan hidupnya. ${ }^{56}$

Dalam konteks ini, tentunya hukum yang ada di Indonesia secara mendalam tidaklah bertentangan dengan sumber-sumber hukum yang dituangkan oleh shari ' (pembuat hukum) dalam kitab suci dan hadis. ${ }^{57}$ Bila kita tilik lebih dalam lagi, maka dalam

53 Ungkapan Izz al-Dīn bin 'Abd al-Salām (w. $660 \mathrm{H}$ ) tersebut seperti halnya ungkapan al-Shātibi, bahwa sebenarnya shari'ah dibuat hanyalah untuk kemanfaatan manusia di dunia dan akhirat secara bersamaan, ia meyakini hal tersebut atas sebuah penelitian, lantas hukum shar'i mengikuti kemanfaatan itu. Ia mengklaim, bahwa shari'ah dibuat hanyalah untuk kemanfaatan manusia. Lihat Wahbah al-Zuhaily, Nazariyat al- Darūrat al-Shar'iyyah, (Beirut: Muasasah alRisalah, tt), 50.

${ }^{54}$ Husein Muhammad, Telaah Atas RUU KUHP Tentang Penodaan Agama”, dalam http://WWW.komnasperempuan.or.id/2013/05/telaah-atas-ruu-kuhp-tentang-

penodaan-agama

${ }^{55}$ Zainuddin Ali, Filsafat Hukum, (Jakarta: Sinar Grafika, 2011), 64-65.

${ }^{56}$ Ibid.

57 Ada banyak ayat Al-Qur'an yang menunjukkan bahwa kita dituntut karikatif dalam mendayagunakan nalar kebangsaan dan nalar transendental sehingga muncul kepatuhan pada hukum yang berimbas pada kebajikan bersama semisal ayat: وَّ أَرََْلْنَاكَ إِلاًَ رَمْمَة لِلْعَالَمِينَ 'Dan Tiadalah Kami mengutus kamu, melainkan untuk (menjadi) 
hukum-hukum shari'ah terdapat unsur kemanfaatan bagi manusia. Asumsi semacam ini akan menimbulkan pemaknaan kuat akan legalitas kemanfaatan sebagai salah satu variabel penetapan hukum. Sedangkan mengikuti pemaknaan kuat adalah suatu keharusan.

Kita bersyukur bahwa bangsa Indonesia telah berhasil merumuskan norma-norma hukum publik fundamental dengan sangat ideal yang disebut Konstitusi Negara Republik Indonesia atau yang dikenal sebagai UUD 1945. Norma-norma ini merupakan hasil konsensus dan diterima oleh seluruh warga Negara bangsa dengan seluruh latarbelakang sosial, budaya, agama, keyakinan, suku, gender dan sebagainya. Fundamentalitas Konstitusi mengandung arti bahwa ia memuat aturan-aturan untuk melindungi hak-hak dasar yang bersifat universal. Hak-hak dasar manusia ini secara garis besar meliputi hak beragama atau berkeyakinan, hak hidup, hak berfikir dan berekspresi, hak atas kesehatan reproduksi, hak atas kehormatan diri, hak atas milik. Dalam konteks Islam hak-hak dasar tersebut merupakan tujuan hukum agama (maqāșìd al-shari'ah). ${ }^{58}$

rahmat bagi semesta alam."(QS. Al-Anbiya':107). Lihat Departemen Agama, AlQur'an al-Karim dan Terjemahnya RI, (Kudus: Menara Kudus 1427 H), 331. Demikian pula, Rasulullah menegaskan bahwa ajaran Islam menegasikan segala macam bentuk destruktif. Dan penegasian ini adalah suatu manfaat. Rasulullah

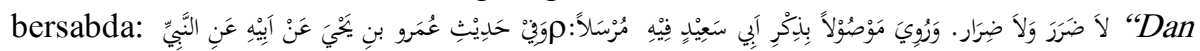
dalam hadis Amr bin Yahya dari ayahnya dari Nabi saw.merupakan hadis mursal "Tidak ada perbuatan destruktif dalam agama, terhadap diri sendiri dan orang lain" dan diriwayatkan secara maushul dengan menyebutkan Abi Sa'id didalamnya." Lihat Al-Baihaqi, al-Sunan al- Șaghïr li al-Baihaqī, Al-Maktabah al-Shämilah, Vol.IV, (CD-Rom: Al-Maktabah Al-Syamilah, Digital, t.t.), 459.

Dalam kitab al-ashbāh wa al-nazāir juga terdapat kaidah yang merupakan penalaran dari hadith tersebut, yaitu: الكضَّرًارُ يُزَّأُ "Suatu bencana atau kemadlaratan itu dihilangkan. "Lihat Al-Suyuți, al-Ashbāh wa al-Naẓāir, vol.I, (Beirut-Lebanon: Dār al-Kutub al-Ilmiah, 2001), 165.

Shari'ah berdiri tegak dengan klaim tujuan yang universal, yaitu: kebahagiaan individu dan golongan, penjagaan terhadap aturan-aturan, menghiasi dunia dengan segala hal yang bisa menyampaikan pada tujuan shari'ah sehingga terwujud kesempurnaan, kebaikan dan peradaban. Dari sini, tampaklah bahwa tujuan dakwah Islam ialah rahmah bagi manusia. Lihat Wahbah, Nazariyat......, 49.

${ }^{58}$ Ibid. Dalam litelatur yang lain dijelaskan, bahwa maqāșìd al-sharí $a h$ ialah tujuan diberlakukannya sebuah hukum, dimana dalam hal ini mencakup lima prinsip dasar universal dari penetapan sebuah hukum, yaitu memeliharanya tegaknya agama (hifz al-din), perlindungan jiwa (hifz al-nafs), perlindungan terhadap akal (hifz al- 'aql), pemeliharaan keturunan (hifz al-nasl) dan perlindungan atas harta kekayaan (hifz 
Bangsa ini patut bersyukur, memiliki calon pemimpin bangsa yang bersemangat dan bertekat untuk memperbaiki keadaan. Mereka mengetahui bahwa persoalan bangsa pada saat ini adalah terletak pada taraf ekonomi rakyat yang masih rendah, tingkat pengangguran yang tinggi dan jumlah lapangan pekerjaan yang semakin terbatas. Beberapa hal inilah yang ingin diprioritaskan untuk ditangani segera jika mereka terpilih menjadi pemimpin bangsa melalui pemilu yang akan datang. ${ }^{59}$

Mengikuti tema-tema kampanye yang disampaikan terkesan calon presiden hanya dituntut lebih untuk menyelesaikan beban tugas pada wilayah yang bersifat terbatas, ialah ekonomi. Seolaholah persoalan bangsa ini hanya terkait dengan ekonomi. Hal ini terjadi, mungkin karena sedemikian yakinnya bahwa persoalan bangsa ini terletak pada persoalan tersebut, hingga mengira bahwa persolan itu hanya bisa diselesaikan dengan pendekatan ekonomi. ${ }^{60}$

Padahal, semestinya persoalan kehidupan, seharusnya dilihat dalam perspektif yang luas. Kehidupan sosial selalu tali temali satu dengan lain secara bersinambungan dan berkelindan. Katakanlah benar bahwa persoalan bangsa ini terletak pada ekonomi, tetapi harusnya disadari bahwa persoalan ekonomi selalu terkait dengan persoalan lainnya, miasalnya pendidikan, hukum, politik, sosial dan bahkan juga budaya. ${ }^{61}$

Oleh karena itu, seorang kepala negara selalu dituntut berkemampuan luas melihat sesuatu persoalan pada perspektif yang luas, mendalam, dan komperhensif. Kehidupan sosial harus dilihat dalam perspektif yang amat luas. Tidak selalu persoalan ekonomi misalnya, hanya bisa diselesaikan oleh seorang ekonom.

al-mā̄). Lihat Aḥmad al-Raisūnī, Nazariat al-Maqāșid 'inda al-Imām al-Shâtīibì (Beirut: Dār al-Kutub al-'Alamiah li al-Kitab al-Islami,1992), 152. maqāsīid alshari' 'ah mencakup lima hal: perlindungan hak hidup (hifz al-nafs), perlindungan hak beragama (hifž al-din), pemeliharaan hak berkeluarga (hifź al-nasl) dan perlindungan atas harta kekayaan (hifz al-mā) dan perlindungan terhadap hak profesi (hifz al-'irdl). Lihat Syaiful Arif, Humanisme Gus Dur, (Yogjakarta: ArRuzz Media, 2013), 284. Lihat juga Al-Ghazali, al-Mustaṣfa min Ilmi al-Uṣūl, (Beirut-Lebanon: Dār al-Kutub al-Ilmiah, 2010), 275. Namun di dalamnya tidak dicantumkan hak profesi (hifz al-'irdl). Di sinilah yang menjadi pembeda antara literatur Humanisme Gus Dur dan al-Mustașfa min Ilmi al-Ușūl. Akan tetapi jumlah yang tetap sama. Yakni lima penjagaan.

59 Imam Suprayogo, Reflesi Pemikiran Menuju Indonesia Baru, (Malang: UIN Maliki Press, 2011), 129.

${ }^{60}$ Ibid.

${ }^{61}$ Ibid. 
Persoalan ekonomi bisa diselesaikan melalui pintu-pintu politik, budaya, hukum dan atau lainnya. Oleh sebab itu seorang presiden, tanpa mengurangi berbagai bekal yang lain, maka bekal kemampuan leadership dan managerial tingkat tinggi adalah sangat diperlukan. ${ }^{62}$

Sebagai seorang leadership setingkat presiden, yang diperlukan adalah kemampuan berimajinasi, mimpi-mimpi, memahami persoalan bangsa pada masa yang lalu, saat ini, dan yang akan datang. Pemimpin bangsa harus mengetahui peta yang luas dan juga tahu dimana letak atau posisi bangsa ini dalam pergumulan jalannya sejarah kehidupan manusia saat ini, dan yang akan datang. Kekuatan apa dan dimana sesungguhnya penggerak kehidupan global ini, perlu dikenali secara baik. Selain itu, tentu saja juga dituntut untuk mengenal secara baik internal bangsa ini sendiri. $^{63}$

Dalam salah satu surat kabar, penulis mengetahui penggalan surat "Dedication of Life" Bung Karno, dimana ungkapan itu sangat menyentuh hati kita, ia berucap:

"Saya adalah manusia biasa. Saya juga tidak sempurna. Sebagai manusia biasa saya tidak luput dari kekurangan dan kesalahan."

Hanya bahagiaku ialah dalam mengabdi kepada Tuhan, kepada tanah air, kepada bangsa. Itulah Dedication of Life-ku.

Jiwa pengabdian inilah yang menjadi falsafah hidupku, dan menikmati serta menjadi bekal hidup dalam seluruh gerak hidupku.

Tanpa jiwa pengabdian ini saya bukan apa-apa. Akan tetapi dengan jiwa pengabdian ini, saya merasakan hidupku bahagia dan manfaat. $^{64}$

\section{Upaya Good Governance}

Upaya mewujudkan pemerintahan yang bersih (clean governance) adalah i'tikad baik yang selalu menjadi agenda politik di setiap periodesasi kepemimpinan. Indonesia merupakan salah satu negara yang terbilang sulit mewujudkan cita-cita itu. Pada tahun 1950-an, Bung Hatta pernah berujar bahwa korupsi telah

\footnotetext{
${ }^{62}$ Ibid.,129-130.

${ }^{63}$ Ibid.

${ }^{64}$ Ikrar Nusa Bhakti, “Kelompok Kohesif dan Capres”, Kompas (13 Maret), 6.
} 
menjadi budaya bangsa. Sekalipun saat itu deklarasi perlawanan terhadap para koruptor telah dikumandangkan, dan tim khusus pemberantas korupsi telah dibentuk, namun pada masa-masa setelahnya, praktik korupsi semakin tak terbendung. ${ }^{65}$ Yang perlu diperhatikan adalah bahwa unsur good governance terdapat tiga hal, yaitu: unsur dalam bidang ekonomi, politik ${ }^{66}$ dan adminitrasi.

65 Subhan Setowara dan Soimin, Agama dan Politik Moral, (Malang: Intrans Publishing, 2013), 88.

${ }^{66}$ Salah satu harapan perbaikan justru datang dari gedung KPK, secara tidak disadari, KPK telah memperkenalkan budaya politik baru yang berpijak pada prinsip tata kelola yang baik dan bersih. Dalam konteks ini cara yang dilakukan KPK adalah memecah konsentrasi individu-individu yang terlibat dalam budaya politik neopatrimonalistik untuk mempertanggung jawabkan korupsi politik yang telah dilakukannya. Tidak berlebihan jika KPK telah membalikkan kemustahilan menjadi sebuah kemungkinan dan harapan. Pengenalan budaya politik baru justru dimulai ketika KPK memecah konsentrasi dan memutus pola relasi patron-klien melalui paradigm impartial law enforcement. Pergeseran paradigm budaya politik ini harus kita dukung bersama dan harus disadari oleh siapa pun yang hendak memasuki domain politik-kekuasaan. Mudah-mudahan langkah KPK memecah konsentrasi neopatrimonalistik ini menandai datangnya era baru budaya politik adiluhung. Jika anda ingin selamat dunia akhirat jangan larut ke dalam sistem politik yang ada, tetapi ciptakanlah sistem politik baru yang akuntabel, bersih, bertanggung jawab dan melayani. Konsekuensinya jika nanti terpilih anda bukan lagi milik parpol dan mengabdi pada parpol, tetapi milik masyarakat dan bangsa ini. Lihat Masdar Hilmy, "Ihwal Budaya Politik Kita", Kompas, (Maret 2014), 7.

Sudah menjadi hal yang lazim, bila kita mendengar politik Islam, maka sejalan dengan itu kita terus berpendapat dan bergumam dalam hati, hal itu adalah tak layak, tak laku dan lain-lain. Terlebih manakala kita lihat, nyatanya politik Islam hanya terkungkung dalam legal formalnya saja. Selayaknya politik yang bernuansa (ramah) Islam menjadi acuan yang mengantarkan pada penerapan nilai keadaban luhur, sebagai penjelmaan al-Islamu ya'lu wa la yu'la 'alaih, begitu sabda Nabi. Pada segi yang lain, acapkali mereka mengungkapkan nilai humanis tapi dalam senyatanya tak terwujud. Inilah bentuk pendangkalan klasik makna humanis. Hendaknya dalam upaya membendung kepentingan sekat-sekat ini perlu adanya dua pendekatan. Yang pertama adalah pendekatan secara kultur yang mengisyaratkan adanya penguatan berpolitik secara kultur -disaat yang bersamaan jiwa kebangsaan yang terpatri dalam lubuk hati manusia kekinian menjelma menjadi aksi-aksi nyata yang melanggengkan patriotisme ke-Indonesiaan. Yang kedua ialah pendekatan yang ramah Islam. Sudah sepantasnya asketisme menjadi rujukan bersama yang mengantarkan pada kebijakan bersama. Apa yang bisa dipahami dari politik kebebasan sosial adalah upaya melakukan kebebasan yang bersyarat -pada waktu yang sama masyarakat dituntut melakukan kontrol sedini mungkin- karena sejatinya keterbukaan melahirkan kebebasan dan selanjutnya masyarakat melakukan kontrol sebisa mungkin, manakala ada penyimpangan yang mengakibatkan kohesi sosial terabaikan. Di sinilah politik kebebasan sosial menunjukkan maghza (signifikasinya) untuk dikembangan secara bersama. Apa 
Pada tahun 1998, siaran pers Tranpransi Internasional. Sebuah organisasi internasional anti korupsi yang bermarkas di Berlin, melaporkan bahwa Indonesia merupakan negara terkorup keenam di dunia setelah lima negara gurem, yaitu Kamerun, Paraguay, Honduras, Tanzania dan Nigeria. Tiga tahun kemudian (2001), Transparansi Internasional justru memasukkan Indonesia sebagai negara terkorup keempat. Dan di tahun 2002, hasil survey Political and Economic Risk Consultancy (PERC) yang bemarkas di Hongkong, menempatkan Indonesia sebagai negara terkorup di Asia. Suvey Nasional Korupsi yang dilakukan oleh Partnership for Governance Reform bahkan melaporkan bahwa hampir setengah dari pejabat pemerintah (48\%) diperkirakan menerima pembayaran tidak resmi. ${ }^{67}$

yang saya maksud dengan politik kebebasan sosial adalah upaya berpolitik dengan berpijak pada dua hal yang saling berkaitan, dalam hal ini adalah pijakan secara kultur dan ramah Islam. Politik Islam hanya akan melahirkan keterpurukan Islam, karena hanya berkutat pada legal formal belaka. Lahirnya keterpurukan bukanlah hal yang baik. Asumsi tersebut mengandung unsur bahaya yang nyata, sedangkan mengikuti unsur tersebut adalah sebuah keburukan. Tawaran politik kebebasan sosial hendaknya juga jangan dipahami secara kasat mata atau sepintas — dalam hal ini perlu adanya pemahaman secara mendalam akan makna politik kebebasan sosial yang berpijak diantara politik (legal formal) Islam dan politik sekuler yang bergaining dengan kebebasan yang sebebas-bebasnya. Pola pikir tersebut mengantarkan pada pergeseran politik dari dua hal yang berbeda menuju pada pemahaman inklusif tentang Islam yang ramah lingkungan dan rahmah bagi semesta alam. Untuk itu derap pergerakan kehidupan yang merupakan keniscayaan hendaknya disikapi dengan terbuka tanpa mengesampingkan etika-moral didalamnya. Di sinilah politik kebebasan sosial melahirkan epistemis yang tidak berseberangan dengan nalar kebangsaan dan nalar transendental. Riuh-rendah budaya politik kita yang berkelindan dengan politik uang -selayaknya dibendung dengan politik (kepentingan) kebebasan sosial yang bernuansa (ramah) Islami. Inilah bentuk pendalaman tentang makna kebebasan sosial yang tidak terpaku pada bentuk formal dan tidak mengesampinkan makna penting yang terkandung didalamnya. Berkaitan dengan budaya politik kita yang kian menunjukkan eksistensinya sebagai sebuah kepentingan temporal dan seksional. Butuh kiranya mendayagunakan politik kebebasan sosial yang terbebas dari kepentingan temporal dan seksional. Inilah agenda besar yang tetap harus digerakkan dan dimassifkan dalam pergumulan berbangsa. Semua itu menandakan desakralitas politik Islam yang berkutat pada bentuk formal dan desakralitas politik sekuler yang menanggalkan makna perjuangan didalamnya. Dengan demikian muncullah istilah politik kebebasan sosial yang patut untuk dibumikan dan dikembangkan secara bersama yang menuntut pada syarat-syarat tertentu yang bersumber dari ajaran agama.

${ }^{67}$ Ibid. 
Sejumlah data diatas menunjukkan bahwa kualiatas clean governance Indonesia berada pada titik yang amat rawan. Sulitnya penanganan terhadap korupsi ini ternyata telah menjadi masalah krusial dalam dunia internasional. Banyak kepala negara yang merasa risau dalam menjalankan kepemimpinannya hanya karena persoalan korupsi. Robert Klit gaard dalam bukunya Membasmi Korupsi (Yayasan Obor Indonesia, 1998), mengutip pernyataan sejumlah kepala negara yang merasa kesulitan dalam mewujudkan clean governance. ${ }^{68}$

Shehu Shagari, Presiden Nigeria di tahun 1982, menyatakan bahwa masalah suap, korupsi, ketidakjujuran dan kurangnya ketaatan dalam menjalankan tugas, merupakan wujud kemerosotan moralitas birokrasi yang paling merisaukan di masa kepemimpinannya. Preseiden Meksiko Jose Lopez Portillo, di akhir masa jabatannya mengakui bahwa banyak rakyat meksiko yang secara tidak halal yang telah mengeruk uang milik negara. Bahkan dalam dua tahun terakhir sebelum ia lengser, menurut Lopez, uang yang dikorupsi lebih banyak daripada yang dijarah kaum imperalis dalam sejarah negara itu. ${ }^{69}$

Pergantian kepemimpinan biasanya menjadi momentum bagi setiap bangsa untuk mewujudkan pemerintahan yang bersih dari segala bentuk penyalahgunaan wewenang (abuse of power). Setelah dibentuknya Komisi Pemberantasan Korupsi (KPK), kita tentunya berharap agar negara bisa lebih mampu menjalankan sistem check and balances dan mekanisme kontrol yang efektif terhadap kekuasaan. Namun, upaya mewujudkan clean government tidak akan menjadi kenyataan jika tidak ada kesadaran kolektif dari masyarakat bahwa korupsi adalah musuh bersama (common enemy). Dengan demikian, solusi pemecahannya tidak bisa diserahkan sepenuhnya kepada KPK. Seluruh elemen bangsa ini perlu meneriakkan genderang perlawanan terhadap korupsi. ${ }^{70}$

Pemberantasan korupsi merupakan agenda berat yang harus dituntaskan oleh pemerintahan sekarang. Hal itu juga harus dibarengi dengan kesadaran bahwa korupsi merupakan masalah kompleks yang tidak disebabkan oleh faktor tunggal. Ada banyak hal yang menyebabkan terjadinya korupsi. Setidaknya, bisa dicatat

\footnotetext{
${ }^{68}$ Ibid.

${ }^{69}$ Ibid.

${ }^{70}$ Ibid.
} 
beberapa factor yang dapat menghambat terwujudnya clean governance dan rumitnya pemberantasan korupsi. ${ }^{71}$

Pertama, kesalahan dalam memilih orang-orang yang akan masuk dalam lingkaran birokrasi serta posisi kunci kekuasaan. Memang birokrasi merupakan organisasi pelaksana pemerintahan yang netral. Namun, maksudnya orang-orang yang salah dalam badan yang netral dapat menyebabkan posisi strategis itu menjadi rawan dan mudah untuk disalahgunakan. Seharusnya ada pola recruitment dengan metode fit and proper test yang ketat dan professional, sehingga yang masuk di dalamnya adalah orangorang pilihan dan memiliki track record yang benar-benar bersih dari KKN. ${ }^{72}$

Kedua, miskinnya moralitas dan pemahaman terhadap ajaran agama. Fritjof Capra dan FDE Schleirmecher pernah menandaskan bahwa krisis budaya, ekonomi dan politik para penguasa yang berada dalam lingkaran kekuasaan. Bangsa ini dijalankan oleh sedikit orang yang berada dijajaran pemerintahan. Maka, baik buruknya negara ini, serta salah satu parameter yang bisa diukur untuk melihat kualitas clean governance di Indonesia adalah bagaimana moralitas para pemimpinnya. ${ }^{73}$

Ketiga, lemahnya rasa cinta terhadap negara (nasionalisme). Bisa dikatakan, bahwa orang-orang yang melakukan praktik KKN, adalah mereka yang telah kehilangan spirit nasionalismenya. Orang yang cinta pada negaranya, tidak mungkin melakukan tindakan yang bisa membuat negaranya menjadi terpuruk. Dalam lingkaran kekuasaan, biasanya jiwa nasionalisme bisa hilang begitu saja tatkala kepentingan pribadi atau golongan menyelinap di dalamnya. Hal itu sangat wajar, karena kekuasaan memang mengandung godaan bagi setiap orang untuk melakukan tindakan penyelewengan: Power tends to corrupt, and absolute power tends to corrupt absolutely, begitu kata Lord Acton. ${ }^{74}$

Masih banyak faktor lain yang menyebabkan terjadinya penyalahgunaan wewenang, seperti kualitas pendidikan yang tidak memadai, kemiskinan, tidak adanya hukuman yang keras terhadap koruptor, kuatnya logika materialisme, bangsa memang benarbenar menghambat negeri ini dalam mewujudkan clean

${ }^{71}$ Ibid., 90.

${ }^{72}$ Ibid.

${ }^{73}$ Ibid.

${ }^{74}$ Ibid.,90-91. 
government. Selain akan menyebabkan high cost economy yang semakin tak terkendali, korupsi juga dapat merusak nilai-nilai serta kepribadian bangsa yang tidak beradab. ${ }^{75}$

Melihat kenyataan di atas, seharusnya setiap momentum politik tidak hanya dijadikan sebagai arena untuk mengejar kekuasaan, akan tetapi harus dimaknai sebagai wadah utntuk memilih pemimpin yang berkualitas. Dengan demikian, presiden yang nantinya memimpin bangsa ini, sebaiknya segera menyiapkan sejumlah jurus ampuh ${ }^{76}$ agar dapat menghadirkan pemerintahan yang bersih. Itu merupakan amanat rakyat yang harus dilaksanakan. ${ }^{77}$

Harus kita akui, bahwa tindak korup ialah masalah klasik mulai zaman Bung Hatta dahulu hingga sekarang yang penanganannya masih terus digalakkan hingga saat ini. Kasus yang menimpa politisi ini hendaknya menjadi bahan renungan bagi politisi yang lain supaya mengindahkan nilai-nilai keadaban yang semakin hari semakin luntur.

Ibarat jurus dalam dunia persilatan nilai-nilai keadaban yang didalamnya terkandung unsur politik kebangsaan atau kenegaraan, politik kerakyatan dan politik etika adalah jurus jitu untuk mewujudkan pemerintahan yang bersih (clean government) sehingga muncul kesejahteraan sosial bagi segenap masyarakat kita. Akan tetapi hal tersebut justru terkesan paradoksal dengan tingkah laku politisi kita yang lebih mementingkan status sosial mereka, dimana mereka memiliki kecenderungan untuk hidup mewah dan glamor. Menurut hemat penulis hal tersebut adalah hal yang wajar karena manusia memang punya keinginan untuk hidup

\section{${ }^{75}$ Ibid.}

${ }^{76}$ Dalam menghadapi turunnya nilai keadaban yang menghinggapi anak bangsa kita saat ini, tampaknya harus ada penangkal atau jurus jitu (ampuh) untuk melawan turunnya nilai keadaban tersebut. Jurus jitu yang harus dikedepankan politisi adalah politik kebangsaan atau kenegaraan, politik kerakyatan dan politik etika. Tanpa pembumian terhadap politik kebangsaan atau kenegaraan, politik kerakyatan dan politik etika tersebut, segala bentuk problematika yang menghinggapi politisi terkait tindak korup dan penindasan sangat sulit bisa terselesaikan. Namun, sayangnya yang lebih banyak muncul dipermukaan panggung perpolitikan mulai zaman dahulu hingga sekarang hanyalah politik kekuasan, dimana politik hanyalah digunakan sebagai alat (instrumen) untuk mencapai kursi jabatan yang empuk sehingga bila kita cermati bersama politik bukanlah sebagai maqasid (perantara) untuk mewujudkan kesejahteraan sosial (social welfare). Sebuah pemandangan yang menyayat hati.

${ }^{77}$ Ibid. 
lebih baik tapi alangkah indahnya bila keinginan untuk hidup lebih baik diimbangi dengan cara-cara yang baik pula.

Bila tingkah laku yang bisa membahayakan orang lain disatu sisi dan membahayakan diri sendiri (bomerang) disisi yang lain masih terus berlangsung maka hal itu menandakan semakin merosotnya nilai-nilai keadaban elit politik kita. Ibarat PRT (Pembantu Rumah Tangga) maka sudah selayaknya Pembantu Rumah Tangga harus memiliki jurus jitu supaya terhindar dari majikannya yang melakukan penindasan dan pelecehan seksual kepada PRT itu, dalam hal ini elit politik yang bertugas mengabdi kepada negara harus memiliki nilai-nilai keadaban untuk menaklukkan tindak korup yang semakin meluas.

Memang dalam kenyataannya menjaga diri dari hal-hal yang membahayakan bagi elit politik bukanlah hal yang mudah untuk dilakukan, karena politik sendiri identik dengan kekuasaan dan kekuasan sendiri bertendensi atau memilki kecenderungan untuk melakukan penyelewengan (tindak korup). Dari sini bila kita cermati bersama bahwa penyelewengan itu bermuara dari tidak adanya penerapan nilai keadaban yang seharusnya berlaku di alam sadar manusia.

Adapun nilai-nilai normatif anti korupsi dalam Islam bisa dilihat dari keharusan pejabat publik yang diangkat memiliki sifat jujur $\left(\right.$ sidq) ${ }^{78}$ dan akuntabel (amānah) ${ }^{79}$. Sifat jujur merupakan sifat

${ }^{78}$ Sifat wajib yang pertama bagi Rasul ialah jujur, yakni berkata berkata benar dalam semua ucapannya. Aksioma yang menunjukkan wajibnya sifat jujur bagi para Rasul ialah apabila mereka berdusta dalam perkara yang mereka sampaikan kepada makhluk, maka berita dari Allah juga dusta. Padahal Allah telah membenarkan pengakuan mereka sebagai utusan dengan menampakkan mukjizat pada mereka. Mukjizat itu sebagaimana Firman Allah dalam hadis Qudsi "Benar hamba-Ku, dalam setiap hal yang ia sampaikan dari-Ku”. Penjelasan aksioma tersebut ialah, bahwa Rasul ketika mendatangi kaumnya dan berkata kepada mereka: "Aku adalah seorang Rasul, Allah telah mengutusku untuk kalian”, lalu mereka berkata: “Apa bukti kerasulanmu?" Dia menjawab: "Berpindahnya gunung ini dari tempat asalnya." Ketika kaumnya berkata: "Buktikan ucapan engkau saat demikian..." Kemudian tatkala waktu yang ditentukan tiba, Allah memindahkan gunung tersebut dari tempat semula, guna membenarkan pengakuan Rasul tadi, maka dipindahnya gunung tersebut oleh Allah, sebagaimana firman-Nya "Benar hamba$K u$, dalam setiap perkara yang ia sampaikan dari-Ku." Seandainya Rasul itu berdusta, maka berita berita dari Allah juga dusta, sedangkan dusta bagi Allah adalah muhal. Dengan demikian menjadi batal lah apa yang mendatangkan pada sesuatu yang muhal tersebut, dalam konteks ini adalah berdustanya seorang Rasul, dan menjadi tetaplah kebalikannya (yakni jujur), inilah yang dicari. Apabila telah 
yang harus dimiliki. Sebagaimana Nabi, pemimpin atau pejabat publik yang dalam batas-batas tertentu melanjutkan tugas-tugas kenabian (memelihara moralitas dan kepentingan duniawi masyarakat), maka kejujuran harus juga dimiliki oleh mereka. Hal ini karena dalam hadis riwayat Bukhari dan Muslim dijelaskan,

tetap bahwa para Rasul memiliki sifat jujur, maka mustahil bagi mereka sifat dusta yang menjadi kebalikan sifat jujur. Lantas apa yang terjadi pada Nabi Ibrahim -

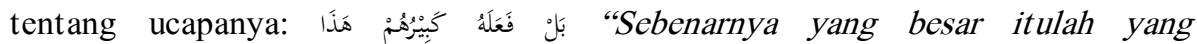
melakukannya". Perkataan itu bukanlah dusta, melainkan termasuk dari bab ta'miyah (mengucapkan lafadz yang mengandung dua makna, makna yang dekat, yakni patung yang besar, dan makna yang jauh yakni orang besar, namun yang dikehendaki disini adalah makna yang jauh yaitu Nabi Ibrahim sendiri) dan termasuk dari bab" mizah (joke/menghibur orang lain tanpa menyakiti). Atau dalam "kata kerja" tersebut terdapat "kata ganti" yang tersimpan, yang kedudukannya sebagai pelaku, dimana "kata ganti" tersebut kembali kepada Nabi Ibrahim yang

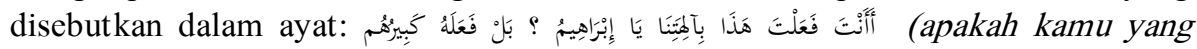
melakukan perbuatan ini terhadap tuhan-tuhan kami, hai Ibrahim?' Nabi Ibrahim menjawab: sebenarnya dialah yang melakukan (yakni Ibrahim). Jadi huruf "ha"” pada lafadz "fa'alahu” statusnya sebagai maf'ul (objek) dan lafadz wakabiruhumhadza statusnya sebagai mubtada' dan khabar. Dan bila demikian berarti berhentinya bacaan pada lafadz "bal fa'alahu”. Mizah (joke) juga pernah dilakukan oleh Nabi Muhammad, yakni ketika datang kepada beliau seorang wanita tua dan bertanya: "Apakah saya masuk surga, wahai Rasul?" Beliau menjawab: “Tidak akan masuk surga seorang nenek-nenek." Wanita itu menangis keras. Lalu Rasul bersabda: “Kamu akan masuk surga dalam keadaan perawan.” Shaikh Ahmad Al-Nahrawi, al-Durru al-Farīd, dicetak bersama Fathu al-Majīd, (Surabaya: alHidayah, t.th.), 41-42.

${ }^{79}$ Sifat wajib yang ke-dua bagi Rasul adalah akuntabel, artinya mereka terpelihara dari melakukan perbuatan yang terlarang atau makruh, baik lahir maupun batin, ketika kecil maupun dewasa. Aksioma yang menunjukkan tetapnya sifat "amanah" bagi para Rasul ialah apabila para Rasul itu berkhianat dengan melakukan perbuatan terlarang atau makruh, berarti kita juga diperintahkan berbuat seperti yang mereka lakukan, karena Allah memerintahkan kita untuk mengikuti Rasul. Tidak dapat dibenarkan bahwa kita diperintah melakukan sesuatu yang haram dan makruh, sebab Allah tidak memerintahkan perbuatan keji. Maka pastilah Rasul tidak melakukan sesuatu kecuali ketaatan, adakalanya berupa wajib atau sunnah. Perbuatan mereka berkisar antara wajib dan sunnah, dan kategori mubah tidak termasuk perbuatan mereka, sebab mereka melakukan perkara yang mubah itu dalam rangka menunjukkan kebolehan perkara tersebut atau untuk keperluan tashri' (menunjukkan hukumnya). Perbuatan yang dilakukan Nabi itu adakalanya wajib adakalanya sunnah. Bila telah tetap bahwa Rasul memiliki sifat amanah (akuntabel) maka mustahil bagi mereka sifat hiyanat (berkhianat) dengan melakukan perbuatan haram atau makruh. Shaikh Ahmad Al-Nahrawi, al-Duru al-Farid, dicetak bersama Fath al-Majid, (Surabaya: al-Hidayah, t.th.),42-43. 
bahwa orang munafiklah ${ }^{80}$ yang perkataannya tidak sesuai dengan realitas yang sesungguhnya atau bertentangan dengan nurani (berbohong). Selain itu dalam hadis muttafaq'alaih juga dijelaskan bahwa kebohongan akan melahirkan kebohongan yang lain demi logikanya dan juga melahirkan tindak keburukan (bohong sebagai pangkal dari dosa). Adapun dosa atau keburukan akan membawa seseorang pada neraka. Jika seorang pemimpin publik melakukan kebohongan berarti ia akan meminta bawahannya untuk melakukan kebohongan. Berdasarkan perspektif ini, korupsi yang berawal dari keharusan antara lain melakukan tindak kebohongan dalam bukti dengan mark up atau memberikan laporan palsu, maka akan melahirkan kebohongan yang dilakukan bersama. Karena itu, korupsi telah merusak realitas data yang sesungguhnya, dan berbahaya. $^{81}$

Sebagaimana para Nabi sebagai teladan, pemimpin atau pejabat publik juga dalam Islam harus "amanah". Kata amanah menunjuk pada kualitas ilmu, keterampilan, dan etis. Artinya, seseorang yang amanah adalah seorang yang profesional yang mampu menjalankan tugasnya dengan efektif dan efisien serta mempunyai komitmen untuk tidak menyelewengkan jabatannya untuk kepentingan yang merugikan publik. Al-Qur'an (QS. Al-Qashas [28]: 26) menyebut syarat minimal pejabat publik adalah seseorang yang memiliki dua kriteria: al-Qawiyy (kuat; memiliki otoritas atau kemampuan, baik keterampilan, intelektual, maupun emosional seperti kuat menghadapi resiko), dan al-amin (terpercaya; kemampuan etis dan juga manajerial). ${ }^{82}$

Pemimpin yang baik adalah yang berani mengambil keputusan berdampak kemajuan, seperti melakukan investasi dalam transportasi massal secara luas, membiayai pendidikan dari tingkat taman kanak-kanak hingga pendidikan tinggi, membangun perindustrian yang menjadi bahan mentah Indonesia produk berharga dengan nilai tambah tinggi, meningkatkan pertanian

${ }^{80}$ Ali bin Abi Thalib pernah berucap: "Sesungguhnya iman itu pasti menampakkan sinar putih, tatkala hamba melakukan perbuatan baik maka sinar putih itu tumbuh dan bertambah sehingga hati menjadi putih dan sesungguhnya nifáq/hipokrit (kemunafikan) itu pasti menampakkan noda hitam, jika hamba melakukan perbuatan tercela maka noda itu tumbuh dan bertambah kemudian membentuk karakter padanya." Lihat Al-Ghazali, Ihya' Ulumiddin, (Surabaya: al-Hidayah, t.th.), 120.

${ }^{81}$ Sukron Kamil, Pemikiran Politik Islam Tematik, (Jakarta: Kencana, 2013), 290.

${ }^{82}$ Ibid., 290-291. 
sehingga Indonesia menjadi pengekspor dan bukan pengimpor beras, kedelai, dan produk pertanian lainnya, serta menjadikan laut sumber kesejahteraan bagi mayoritas bangsa. ${ }^{83}$

Namun, kita juga memerlukan manusia-manusia lain yang sangat berkiprah di bidangnya dan menghasilkan kemajuan yang penting bagi bangsa. Sekarang kita bangga ada Emirsyah Satar yang menjadikan Garuda Indonesia dipercaya, Rismaharini sebagai wali kota yang membangun taman-taman indah di Surabaya dan membuatnya rakyatnya lebih bahagia. ${ }^{84}$ Tentu kita ingin prestasi

${ }^{83}$ Sayyidiman Suryohadiprojo, "Manusia dan Sistem Sama Penting", Kompas (Februari 2014), 6.

${ }^{84}$ Salah satu ramuan paling mujarab di balik rahasia kepemimpinan Risma adalah penggunaan akal sehat (Common sense) pada tingkat paling maksimal. Memang terdengar sederhana, tetapi terbukti ampuh mengantarkan kota yang dipimpinnya meraih banyak penghargaan, baik ditingkat nasional maupun internasional. Melalui akal sehat, Risma telah mempertontonkan kualitas dan integritas kepemimpinan prima untuk melayani seluruh warga kota Surabaya. Satu per satu masalah terselesaikan: dari urusan sampah, tata kota yang semrawut, kemacetan, hingga banjir tahunan. Tanpa pendayagunaan akal sehat, segala bentuk permasalahan kota mustahil bisa terselesaikan dalam waktu relatif singkat. Wajah kota sekarang jauh berbeda dibandingkan lima atau 10 tahun lalu. Kini Surabaya menjadi kota yang ramah, layak huni (livable), bahkan "mengasuh" bagi jiwa-jiwa metropolitan yang kering dan gersang serta menginspirasi produktivitas warganya. Sejumlah taman kota nan asri, area pedestrian bagi pejalan kaki, lajur khusus bagi pengguna sepeda, penerapan hari bebas kendaraan bermotor di hari minggu adalah sebagian kecil dari sentuhan "tangan dingin" Risma dalam mengedepankan akal sehat. Konsistensi dan kengototan Risma dalam mererapkan akal sehat harus ditebus mahal. Dia menerima banyak tekanan dari penentangnya. Konon, ancaman mati bahkan sudah menjadi menu kesehariannya. Moral yang bisa dipetik dari nestapa seorang Risma: ternyata akal sehat itu baik untuk warga, tetapi belum tentu baik bagi para pemodal dan pengusaha nakal. Ibarat jamu, ia abaik bagi kesehatan tubuh, tetapi terasa pahit di lidah. Sebuah paradoks yang pada akhirnya harus saling menegasikan. Inilah aksioma politik muatakhir yang menggabarkan pertarungan kekuatan baik versus kekuatan jahat dalam jagad politik kekuasaan. "Kesalahan" Risma -yang kemudian terbukti menjadi kabar baik bagi warga kota- adalah upayanya melakukan redistribusi kesejahteraan dan kenyaman bersama berdasarkan prinsip-prinsip public good. Dia telah menutup keran akses kesejahteraan bagi bagi segelintir elite di satu sisi, teapi juga membukanya bagi sebagian besar warga kota di sisi lain. Prinsip public good yang ia terapkan jelas mengusik kenyamanan para pemodal busuk, tetapi telah berhasil menciptakan keadilan distributif bagi semakin banyak warga kota dalam konteks yang lebih luas, "kesalahan" Risma dalam waktu bersamaan juga adalah "kebenaran" public. Ibarat mengkonsumsi jamu, maka rasa pahit adalah kesalahan bagi lidah, tetapi kesehatan adalah kebenaran bagi tubuh. Jika kita ingin sehat, maka pilihannya bukan menghindar dari jamu, tetapi tetap mengkonsumsinya sekalipun terasa pahit. Demikianlah, akal sehat terbukti 
mereka makin meningkat dan mendorong yang lain untuk lebih berprestasi. $^{85}$

Dengan manusia dan sistem yang sesuai pancasila, Indonesia akan menjadikakan rakyatnya maju, sejahtera lahir batin, dan sanggup berperan aktif dalam kesejahteraan umat manusia. ${ }^{86}$

Kita butuh banyak figure dengan karakter mampu (enabler) bukan pelengkap (provider), leader bukan dealer, pemimpin bukan pembesar. Negarawan otentik dengan visi melenting ke depan, bukan kontestan yang menjual keajaiban. Konfigurasi tantangan dan beban negara menghendaki ekspresi keteguhan sikap, keputusan, dan tindakan yang menyatukan visi bersama. ${ }^{87}$

Kita tidak memilih seorang presiden biasa yang mudah berjanji, tetapi belum cukup memberi di lapangan pengabdian kemasyarakatan dan kebangsaan. Perlu banyak tokoh teladan yang dapat membangkitkan tekad untuk memecahkan begitu banyak kebuntuan, bersendikan misi kuat, terukur, dan terencana. Figurfigur dengan dukungan mencukupi dari berbagai kalangan, mampu merangkum cita-cita bangsa, dan mengobarkan semangat dan hasrat besar agar Indonesia meraih martabat semestinya. ${ }^{88}$

Kita butuh para pemimpin yang bisa meningkatkan kapasitas bangsa menggapai daya saing tinggi, tetapi sekaligus mengembangkan daya sanding kohesif. Pemimpin yang paham mengendalikan kompetisi yang seringkali memakan korban pihak paling lemah, sekaligus kerjasama untuk saling berbagi ruang dan peluang. ${ }^{89}$

Tokoh yang hendak bermetamorfosis jadi pemimpin sejati sepatutnya mengerti makna konfesi, tugas utama seorang manusia pilihan sebagai reprentasi makhluk mulia yang suka-cita mengusung "titipan" kebajikan-kebajikan besar. Bagaimana ia menunaikan tugas itu, menunjukkan sejauh mana drajat konfesinya. ${ }^{90}$ Alhasil pemimpin sejati yang memahami secara baik

menajadi ramuan ampuh dalam mengurai dan menyelesaikan segudang persoalan yang mengepung Surabaya. Lihat Masdar Hilmy, "Membunuh Akal Sehat", Kompas, (Maret 2014), 7.

${ }^{85}$ Sayyidiman Suryohadiprojo, "Manusia dan Sistem Sama Penting", Kompas (Februari 2014), 6.

${ }^{86}$ Ibid.

${ }^{87}$ Suwidi Tono, “Tugas Sejarah Presiden Baru”, Kompas (Februari 2014), 6.

${ }^{88}$ Ibid.

${ }^{89}$ Ibid,

${ }^{90}$ Ibid,. 
dan mendalam atas konfesi, akan berimbas dalam pelaksanaannya terhadap tugas yang sudah dipercayakan kepadanya, dimana dalam senyatanya ia mampu mendayagunakan nalar kebangsaan dan nalar transendental yang ia labuhkan di dalam lubuk hati dan kemudian ia aksikan dalam realita kehidupan berbangsa.

\section{Penutup}

Secara sederhana negara adalah suatu organisasi dalam suatu wilayah yang memiliki kekuasaan tertinggi yang sah dan ditaati oleh rakyatnya. Pancasila dalam pengertian (asas negara pancasila) sering disebut dasar falsafah negara (filosofische gronslag), ideology negara (staatidee). Dalam hal ini pancasila digunakan sebagai dasar mengatur pemerintahan negara atau dengan kata lain pancasila digunakan sebagai dasar untuk mengatur penyelenggaraan negara. Hukum adalah rangkain peraturan-peraturan mengenai tingkah-laku orang-orang sebagai anggota suatu masyarakat, yang bersifat memaksa, untuk mengadakan tata tertib diantara anggota-anggota masyarakat dalam rangka melindungi kepentingan-kepentingan orang dalam masyarakat itu. Upaya mewujudkan pemerintahan yang bersih (clean governance) adalah i'tikad baik yang selalu menjadi agenda politik di setiap periodesasi kepemimpinan. Indonesia merupakan salah satu negara yang terbilang sulit mewujudkan cita-cita itu. Pada tahun 1950-an, Bung Hatta pernah berujar bahwa korupsi telah menjadi budaya bangsa. Sekalipun saat itu deklarasi perlawanan terhadap para koruptor telah dikumandangkan, dan tim khusus pemberantas korupsi telah dibentuk, namun pada masa-masa setelahnya, praktik korupsi semakin tak terbendung. Dengan demikian perlu adanya upaya secara rutin dalam rangka menciptakan tata kelola pemerintahan yang baik dan menyenangkan.

Dalam sebuah wilayah yang bernama negara, bisa dipastikan di dalamnya terdapat komposisi rakyat dan wakil rakyat, dimana dalam konteks ini, wakil rakyat merupakan pengejawantah (penjelmaan) dari utusan rakyat dalam menjalankan roda pemerintahan. Bila ditarik ke atas kita akan menjumpai pemimpin negara, dimana dalam negara Indonesia kita mengenal istilah Presiden. Sejauh ini, jika kita mencermati negara kita, tampaknya banyak sekali problem yang menimpa negara kita, diantara problem yang paling menonjol adalah tindak korup yang dilakukan para pejabat kita, maka dengan segala problem kompleks ini, kita dituntut untuk terus merenung, berpikir dan melakukan terobosan-terobosan hebat, sehingga ke depannya, 
Indonesia benar-benar menjadi negara yang pemerintahnya bersih dan baik. Dalam menghadapi masalah yang kompleks ini, kiranya dibutuhkan beberapa pembangunan, di antaranya pertama, pembangunan infrastruktur, yang berimplikasi pada perbaikan jalan, jembatan dan sarana-sarana lain yang berwujud kebendaan yang bisa mendukung kemajuan Indonesia. Kedua, pembangunan suprastruktur yang meliputi permasalahan-permasalahan klasik yang melanda Indonesia, seperti pemberantasan tindak korup, pemutusan dari intervensi pihak asing dan lain sebagainya. Selanjutnya berbagai masalah itu, bisa saja dipangkas dengan melakukan beberapa pendekatan, yakni pertama, pendekatan secara struktur, dimana dalam hal ini yang diketengahkan ialah kesetaraan dalam tingkatan yang pada akhirnya berimplikasi pada tidak ada perbedaan dalam agama, suku, ras dan lain sebagainya yang bisa membahayakan kemajuan Indonesia, Kedua pendekatan sosio-kultural, dimana dalam hal ini yang diusung ke ranah publik adalalah penyadaran akan nilainilai humanis dalam kegiatan hidup di dunia ini dan yang paling urgent ialah bahwa kita satu negara, yakni negara Indonesia. Selanjutnya dengan optimisme dalam diri kita semua, bukan tidak mungkin, kita akan menjumpai wajah Indonesia yang lebih bersinar dan bermartabat, karena konsep good governance dapat digapai. Ini tidak mustahil atau utopis belaka, manakala semua elemen mau bersatu padu untuk mewujudkan praksis yang lebih baik, dan mewujudkan pembebasan diri dari alam bawah sadar, karena dalam alam bawah sadar terkandung rasa dahaga dan mengingingkan orang lain untuk bertekuk lut ut kepada individu yang lain. Hal ini tentunya harus dibendung sebisa mungkin, bila tidak ada pembebasan, maka semuanya akan menjadi semakin carut-marut. Kendati demikian, Prospek good governance di Indonesia akan ikut diwarnai oleh oknum-oknum yang tidak bertanggungjawab yang berupaya menegasikan konsep good governance sebagai perwujudan banalitas mereka akan pemaknaan "kemanusiaan yang adil dan beradab" dan penjelmaan dari dangkalnya pemahaman dari ungkapan al-Islämu ya'lu wa la yu'la 'alaih, begitu sabda Nabi bagi mereka yang beragama Islam. Jika penegasian itu identik dengan orang-orang yang bodoh dan tak berpendidikan tinggi, nyatanya mereka semua pandai dan berpendidikan tinggi. Bila kita cermati perbuatan buruk bagi mereka yang ingin menegasikan konsep good governance dan perbuatan baik bagi mereka yang mengusung konsep good governance, maka itu merupakan potret watak manusia yang hidup 
dan berpolitik yang di dalamnya ada unsur baik di satu sisi dan unsur buruk di sisi yang lain yang saling berlawanan. Kiranya sudah menjadi sunnatullah, tinggal bagaimana manusianya mau berupaya dan berpasrah diri kepada Yang Maha Kuasa. Dari sini dapat kita pahami, bahwa politik adalah rokok, semakin ia dihisap atau disedot oleh pelakunya, perokok akan semakin kecanduan untuk merokok atau politik itu kopi, semakin dirasa oleh peminum kopi, ia akan semakin merasakan kenikmatan, karena politik adalah pemuas dahaga, sehingga pelakunya mendapatkan kebahagiaan secara nyata. Dari sini pula, peran pemimpin yang jujur dan tegas sangat dibutuhkan supaya bangsa ini tak lagi putus asa dalam menjalani praksis di dunia fatamorgana ini. Dengan demikian tawaran pembumian konsep good governance yang mengusung wilayah hati nurani dan akal sehat masih menunjukkan signifikasinya untuk "dilirik", dilaksanakan, dan dikembangkan secara bersama.

\section{Daftar Pustaka}

A'la, Abd, "Mewaspadai Penyalahgunaan Kekuasaan” dalam http://WWW. uinsby.ac.id/index.php/19-uinsa/kolom-akade

misi/113-penggunaan-kekuasaaan-signifikansi-substantif

Ali, Zainuddin. Filsafat Hukum. Jakarta: Sinar Grafika, 2011.

Affendi, Abdel Wahab (el). Masyarakat Tak Benegara: Kritik Teori Politik Islam. Yoyakarta: LKiS, 2012.

Nahrawi, Shaikh Ahmad (al). al-Durr al-Farid, dicetak bersama Fath al-Majid. Surabaya: al-Hidayah, t.th.

Arif, Syaiful. Humanisme Gus Dur: Pergumulan Islam dan Kemanusiaan. Yogyakarat: Ar-Ruzz Media, 2013.

Baihaqi (al), al-Sunan al- Saghìr li al-Baihāqī. CD-Rom: AlMaktabah Al-Syamilah, Digital, t.th.

Budiardjo, Miriam. Dasar-Dasar Ilmu Politik. Jakarta: Gramedia, 2010.

Daud Busroh, Abu. Imu Negara. Jakarta: Bumi Aksara, 2011.

Departemen Agama. Al-Qur'an al-Karim dan Terjemahnya RI. Kudus: Menara Kudus $1427 \mathrm{H}$.

Echols, John M. dan Shadily, Hassan. Kamus Inggris Indonesia. Jakarta: Gramedia, 2008.

Ghazali (al). al-Mustaṣfã min Ilmi al-Uṣūl. Beirut: Dār al-Kutub alIlmiah, 2010.

Ghazali (al). Ihya' Ulumiddin. Surabaya: al-Hidayah, t.th. 
Hadi Pernomo, Sjechul. "Relevansi Filsafat Hukum Nasional Dan Filsafat Hukum Islam: Suatu Tinjauan Komparatif". Akademika. Vol.14, No.2, Maret, 2004.

Hilmy, Masdar. "Banalitas Demokrasi Kita". Kompas. Januari 2014. Hilmy, Masdar. "Membunuh Akal Sehat". Kompas. Maret 2014. Hilmy, Masdar. "Demokrasi Roller Coaster". dalam http://WwW. uinsby.ac.id/index.php/19-uinsa/kolom-akade misi/119-demokrasi-roller-coaster

Hilmy, Masdar. "Ihwal Budaya Politik Kita". Kompas. Maret 2014. Huda, Ni'matul. Ilmu Negara. Jakarta: Rajagrafindo Persada, 2013. Ihsan, A. Bakir. Etika dan Logika Berpolitik. Bandung: Rosdakarya, 1999.

Kamil, Sukron. Pemikiran Politik Islam Tematik. Jakarta: Kencana, 2013.

Kansil. Pengantar Ilmu Hukum Dan Tata Hukum Di Indonesia. Jakarta: Balai Pustaka, 1986.

Khairi, Moh. "Harapan Pemilu Kita". dalam http://politik.kompasiana.com/2014/03/22/harapan-pemil ukita-641518.html

Mahfudh, MA. Sahal. Nuansa Fiqh social. Yogyakarta: LKiS, 2011.

Magnis Suseno, Franz. Kedaulatan Rakyat, Bukan Kedaulatan Tuan. Kata Pengantar dalam Muhammad AS Hikam. Demokrasi Dan Civil Society. Jakarta: LP3ES, 1999.

Muhammad, Husein. Telaah Atas RUU KUHP Tentang Penodaan Agama", dalam http://WWW.komnas perempuan.or.id/2013/05/telaah-atas-ruu-kuhp-tentang-pe nodaan-agama

Nusa Bhakti, Ikrar. "Kelompok Kohesif dan Capres". Kompas. 13 Maret.

Raisuni, Ahmad (al). Nazariat al-Maqāsid 'inda al-Imām al-Shätibi. Beirut: Dar al-Kutub al-'Alamiah li al-Kitab al-Islami,1992.

Setowara, Subhan, dan Soimin. Agama dan Politik Moral. Malang: Intrans Publishing, 2013.

Suyuthi (al), al-Ashbah wa al-Nazāirr. Beirut: Dar al-Kutub al-Ilmiah, 2001.

Suprayogo, Imam. Reflesi Pemikiran Menuju Indonesia Baru. Malang: UIN Maliki Press, 2011.

Suryohadiprojo, Sayyidiman. "Manusia dan Sistem Sama Penting". Kompas. Februari 2014. 
Sjadzali, Munawir. Islam Dan Tata Negara: Ajaran, Sejarah dan Pemikiran. Jakarta: UI Press, 1993.

Shihab, Alwi. Islam Inklusif: Menuju Sikap Terbuka Dalam Agama. Bandung: Mizan, 1999.

Tono, Suwidi. "Tugas Sejarah Presiden Baru”. Kompas. Februari 2014.

Triwulan Tutik, Titik. Kontruksi Hukum Tata Negara Indonesia Pasca Amandemen UUD 1945. Jakarta: Kencana, 2011.

Triwulan Tutik, Titik. Pengantar Ilmu Hukum. Jakarta: Prestasi Pustaka, 2006.

Wahid, Salahuddin. "Pejabat Jujur Sulit Dicari". Kompas. Maret 2013.

Wahyudi, Chafid. NU \& Civil Religion: Melacak akar civil religion dalam keagamaan NU. Yogyakarta: Graha Ilmu, 2013.

Zakariyah al-Anshari, Yahya. Gha.yah al-Wusūl. Surabaya: alHidayah, t.th.

Zuhaily, Wahbah (al). Nazariyat al-Darürah al-Shar'iyah. Beirut: Muasasah al-Risalah, t.th. 